\title{
GABAergic Transmission to Kisspeptin Neurons Is Differentially Regulated by Time of Day and Estradiol in Female Mice
}

\author{
Richard A. DeFazio, ${ }^{1}$ Carol F. Elias, ${ }^{1,2}$ and Suzanne M. Moenter ${ }^{1,2,3}$ \\ Departments of ${ }^{1}$ Molecular and Integrative Physiology, ${ }^{2}$ Obstetrics and Gynecology, and ${ }^{3}$ Internal Medicine, University of Michigan, Ann Arbor, Michigan \\ 48109
}

Gonadotropin-releasing hormone ( $\mathrm{GnRH})$ secretion is regulated by estradiol feedback. This feedback switches from negative to positive in females; this switch depends on time of day in many species. Estradiol feedback is likely conveyed via afferents. Kisspeptin neurons of the arcuate nucleus and anteroventral-periventricular region (AVPV) may differentially regulate GnRH neurons during negative and positive feedback, respectively. We tested estradiol and time of day regulation of GABAergic transmission and postsynaptic response to GABA in these two populations using transgenic mice with GFP-identified kisspeptin neurons. Ovariectomized (OVX) mice treated or not

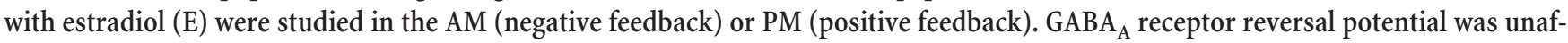
fected by time of day or estradiol. GABA depolarized the membrane potential of arcuate neurons from OVX $+\mathrm{E}$ mice; this response was blunted in cells from OVX mice. GABA hyperpolarized AVPV kisspeptin neurons, except in the OVX PM group in which GABA did not alter membrane potential attributable to a PM hyperpolarization of baseline membrane potential. In both kisspeptin neuron populations from OVX mice, the frequency of GABAergic spontaneous postsynaptic currents was increased in the PM; this increase was blunted by estradiol. In arcuate, but not AVPV, kisspeptin neurons, estradiol reduced miniature postsynaptic current amplitude independent of time of day. Using nonstationary fluctuation analysis and diazepam to manipulate $\mathrm{GABA}_{\mathrm{A}}$ receptor apparent affinity, the decrease in arcuate miniature postsynaptic current amplitude was attributed to decreased number of receptors bound by GABA. Time of day and estradiol feedback thus both target presynaptic and postsynaptic mechanisms to differentially regulate kisspeptin neurons via GABAergic transmission.

Key words: diurnal; estradiol; feedback; GnRH; kisspeptin; membrane potential

\section{Introduction}

Gonadotropin-releasing hormone ( $\mathrm{GnRH})$ neurons form the final common pathway for central control of female reproduction. Feedback from steroids, such as estradiol, regulates GnRH release. During most of the reproductive cycle, estradiol negative feedback suppresses GnRH release (Christian and Moenter, 2010). Peak levels of estradiol produced by mature ovarian follicles induce a switch in estradiol action to positive, generating a surge of GnRH release as a central signal for ovulation (Sarkar and Fink, 1979; Karsch et al., 1987; Moenter et al., 1990, 1991).

\footnotetext{
Received July 23, 2014; revised 0ct. 16, 2014; accepted 0ct. 20, 2014.

Author contributions: R.A.D. and S.M.M. designed research; R.A.D. performed research; C.F.E. contributed unpublished reagents/analytic tools; R.A.D. and S.M.M. analyzed data; R.A.D. and S.M.M. wrote the paper.

This work was supported by National Institutes of Health/Eunice Kennedy Shriver National Institute of Child Health and Human Development R01 HD41469 to S.M.M. and HD69702 to C.F.E. We thank Elizabeth Wagenmaker and Laura Burger for expert technical assistance; Luhong Wang, Kristen Ruka, Elizabeth Wagenmaker, Laura Burger, and Pei-San Tsai for editorial comments; and James L. Kenyon (University of Nevada, Reno, Nevada) for the Excel spreadsheet used to calculate junction potentials.

The authors declare no competing financial interests.

Correspondence should be addressed to Dr. Richard A. DeFazio, Department of Molecular and Integrative Physiology, University of Michigan, 7725 Med Sci II, 1137 E. Catherine Street, Ann Arbor, MI 48109-5622. E-mail: defazio@umich.edu.

DOI:10.1523/JNEUROSCI.3057-14.2014

Copyright $\odot 2014$ the authors $\quad 0270-6474 / 14 / 3416296-13 \$ 15.00 / 0$
}

The switch from negative to positive feedback is often coupled to time of day. This is evident in females that are ovariectomized and given implants producing continuous physiologic estradiol levels (Norman et al., 1973; Legan and Karsch, 1975). In this daily surge model, GnRH activity and release are suppressed in the morning (negative feedback) and enhanced in the evening near lights out (positive feedback) over several days (Christian et al., 2005; Glanowska et al., 2012). In contrast, no diurnal changes in GnRH activity are observed in ovariectomized mice not treated with estradiol (Christian et al., 2005). Estradiol is thus required for $\mathrm{GnRH}$ neuron function to change with time of day. How the central network driving GnRH output integrates estradiol and time of day is unknown.

Classical actions of estradiol via estrogen receptor $\alpha(\mathrm{ER} \alpha)$ are key to mediating feedback (Christian et al., 2008), yet ER $\alpha$ is typically not detectable in GnRH neurons (Herbison and Theodosis, 1992; Herbison et al., 1993; Lehman et al., 1993; Hrabovszky et al., 2000). $\mathrm{ER} \alpha$ is, however, expressed by kisspeptin-expressing neurons of the arcuate nucleus and anteroventral-periventricular region (AVPV), and these populations appear to synapse on GnRH neurons (Hrabovszky et al., 2010; Lehman et al., 2010). Kisspeptin is a potent activator of GnRH neurons (Han et al., 2005; Dumalska et al., 2008; Pielecka-Fortuna et al., 2008). Interestingly, kisspep- 
tin neurons of the AVPV exhibit circadian-dependent changes in gene expression, including cFos, an indirect marker of neuronal activity (Robertson et al., 2009). The expression of ER $\alpha$ and the differential modulation of kisspeptin mRNA expression by estradiol (Smith et al., 2005) have led to speculation that kisspeptin neurons of the arcuate nucleus and AVPV are prime mediators of estradiol negative and positive feedback, respectively (Oakley et al., 2009).

How time of day is transmitted to kisspeptin neurons and whether this is estradiol-dependent are unknown. The suprachiasmatic nucleus is a GABAergic nucleus that contains the primary circadian clock (Kalsbeek et al., 2006; Miller and Takahashi, 2013) and projects to both the AVPV (Vida et al., 2010; Williams et al., 2011) and the arcuate nucleus (Watts and Swanson, 1987; Watts et al., 1987; Saeb-Parsy et al., 2000). Kisspeptin neurons receive GABAergic synaptic input (Frazão et al., 2013), but how these neurons respond to $\mathrm{GABA}_{\mathrm{A}}$ receptor activation is unknown, as is the interaction between estradiol feedback and time of day in regulating transmission or response. Using the daily GnRH/luteinizing hormone (LH) surge model, we examined GABA reversal potential, baseline membrane potential, response to GABA, and GABAergic synaptic transmission in hypothalamic kisspeptin neurons.

\section{Materials and Methods}

Animals. Kisspeptin-hrGFP mice (Cravo et al., 2013) and Tac2-enhanced green fluorescent protein (GFP) BAC transgenic mice (015495-UCD/ STOCK Tg (Tac2-EGFP)381Gsat, Mouse Mutant Regional Resource Center) (Ruka et al., 2013) were propagated in our colony. All mice had ad libitum access to Harlan 2916 chow and water and were held on a 14 L:10D light cycle with lights on at 4:00 A.M. (AM) Eastern Standard Time. Adult female mice 60-90 d old were ovariectomized (OVX) under isoflurane anesthesia with bupivacaine as an analgesic; some mice were treated with estradiol $(\mathrm{OVX}+\mathrm{E})$ via SILASTIC implants as described previously (Christian et al., 2005). Studies were done 2-4 d after surgery; no differences were observed with either time after surgery or with genotype, and data have been combined. The University of Michigan University Committee on the Use and Care of Animals approved all procedures.

Brain slice preparation. All reagents were purchased from Sigma unless noted. All solutions were bubbled with $95 \% \mathrm{O}_{2} / 5 \% \mathrm{CO}_{2}$ throughout the experiments and for at least $30 \mathrm{~min}$ before exposure to tissue. Brain slices were prepared through the preoptic area and hypothalamus as previously described (DeFazio et al., 2002). Slices for recordings during negative feedback (AM) were prepared from 8:00 to 10:00 AM and recorded from 11:00 AM to 1:30 PM; slices for recording during positive feedback (PM) were prepared from 3:00 to 4:00 PM and recorded from 5:00 to 7:00 PM (all times Eastern Standard Time). The brain was rapidly removed and placed in ice-cold sucrose saline solution containing the following (in mm): 250 sucrose, $3.5 \mathrm{KCl}, 26 \mathrm{NaHCO}_{3}, 10$ glucose, $1.25 \mathrm{NaHPO}_{4}, 1.2$ $\mathrm{MgSO}_{4}$, and $3.8 \mathrm{MgCl}_{2}$. Coronal $(300 \mu \mathrm{m})$ slices were cut with a Vibratome 3000 (Ted Pella) or Leica VT1200S (Leica Biosystems). Slices were incubated for $30 \mathrm{~min}$ at room temperature $\left(\sim 21^{\circ} \mathrm{C}-23^{\circ} \mathrm{C}\right)$ in $50 \%$ sucrose saline and 50\% ACSF containing the following (in $\mathrm{mm}$ ): 135 $\mathrm{NaCl}, 3.5 \mathrm{KCl}, 26 \mathrm{NaHCO}_{3}, 10$ D-glucose, $1.25 \mathrm{Na}_{2} \mathrm{HPO}_{4}, 1.2 \mathrm{MgSO}_{4}, 2.5$ $\mathrm{CaCl}_{2}, \mathrm{pH}$ 7.4. Slices were then transferred to $100 \%$ ACSF solution at room temperature for $0.5-6 \mathrm{~h}$ before recording.

General recording solutions and data acquisition. Two pipette solutions were used with low and high chloride concentrations. Low chloride solution consisted of the following (in $\mathrm{mM}$ ): $139 \mathrm{~K}$ gluconate, $1 \mathrm{KCl}, 10$ HEPES, 5 EGTA, $0.1 \mathrm{CaCl}_{2}, 4 \mathrm{MgATP}$, and $0.4 \mathrm{NaGTP}$, pH 7.2 with $\mathrm{NaOH}$; for high chloride K gluconate was replaced with $\mathrm{KCl}$. Recording pipettes containing either high or low chloride were used with similar results after liquid junction correction of 4.8 and $16 \mathrm{mV}$, respectively (Barry, 1994). All voltages reported are corrected for liquid junction potential. The bath solution for recording was $100 \%$ ACSF plus $20 \mu \mathrm{M}$ APV and $10 \mu \mathrm{M}$ CNQX to block ionotropic glutamatergic receptors, and
SCH50911 to block $\mathrm{GABA}_{\mathrm{B}}$ receptors. Tetrodotoxin $(1 \mu \mathrm{M})$ was included except when action currents or action potentials were monitored, as detailed below. During recording, slices were continuously superfused at $2 \mathrm{ml} / \mathrm{min}$ with oxygenated bath solution kept at $30^{\circ} \mathrm{C}$ with an inlineheating unit (Warner Instruments). GFP-positive cells were visualized with a combination of infrared differential interference contrast and fluorescence microscopy on an Olympus BX50WI microscope. Recordings were made with an EPC-10 dual patch-clamp amplifier (HEKA Elektronik) and a Macintosh computer running Patchmaster software (HEKA Elektronik). Membrane currents were filtered at $5 \mathrm{kHz}$ and digitized at $10 \mathrm{kHz}$. Each of the experiments reported below was analyzed offline using custom software (DeFazio et al., 2002) written in IgorPro (Wavemetrics).

GABA application. Local pressure application of GABA was accomplished as previously described (DeFazio et al., 2002). Patch pipettes (2-4 $\mathrm{M} \Omega$ ) were filled with a HEPES-buffered saline (containing in mM: 150 $\mathrm{NaCl}, 10 \mathrm{HEPES}, 10$ glucose, $3.5 \mathrm{KCl}, 2.5 \mathrm{CaCl}_{2}, 1.3 \mathrm{MgCl}_{2}, \mathrm{pH} 7.2$ with $\mathrm{NaOH}$ ) similar to the extracellular solution with the addition of $100 \mu \mathrm{M}$ GABA. The pressure pipette was placed adjacent to the soma, and a $30-50 \mathrm{~ms}$ pulse of 3-10 psi was delivered using a WPI PV820 picospritzer. Pressure application of the HEPES-buffered solution alone had no effect (data not shown).

Gramicidin-perforated patch recordings. Gramicidin-perforated patch recordings were performed using a modification of previously described methods (DeFazio et al., 2002). Patch pipettes (2-5 M $\Omega$ ) were first filled with 1.25-1.75 $\mu \mathrm{l}$ of filtered, gramicidin-free internal solution, then backfilled with freshly sonicated, unfiltered pipette solution containing $10-50 \mu \mathrm{g} / \mathrm{ml}$ gramicidin $\mathrm{D}$; similar series resistance was achieved with all concentrations, but higher concentrations produced a greater percentage of quality recordings. Gramicidin stock solution was prepared every 1-3 $\mathrm{h}$ at $50 \mathrm{mg} / \mathrm{ml}$ in DMSO. Access resistance of gramicidin perforated patch recordings was monitored regularly throughout the experiment. Voltage-clamp recordings of the GABA reversal potential were initiated when the access resistance fell $<100 \mathrm{M} \Omega$ (range $25-100 \mathrm{M} \Omega$ ). Rupture of perforated patch recordings to whole-cell mode was detected by an abrupt decrease in access resistance associated with a dramatic change of the reversal potential.

Voltage steps $(10 \mathrm{mV})$ bracketing the reversal potential were used; GABA was delivered as described $>200 \mathrm{~ms}$ into the voltage step; this allowed the membrane current to stabilize before treatment (see Fig. 1). Voltage steps and accompanying GABA puffs were delivered at $30 \mathrm{~s}$ intervals to prevent changes in intracellular chloride attributable to accumulation or depletion during the GABA current (Defazio and Hablitz, 2001). Baseline current was measured just before the GABA pulse; GABA-induced current was measured $100 \mathrm{~ms}$ after rapid GABA application. The step potential was corrected for series resistance independently for each measurement based on the absolute current, the series resistance and Ohm's law $\left(\mathrm{V}_{\text {corrected }}=\mathrm{V}_{\text {step }}-\mathrm{V}_{\text {error }} ; \mathrm{V}_{\text {error }}=\mathrm{I} \times \mathrm{R}_{\text {series }}\right)$. The reversal potential was determined from the crossing of the current-voltage relationship of the baseline current and the GABA response using a custom-written computer program running under IGOR Pro and verified by eye for each reversal. Only reversals that were stable $(<5 \mathrm{mV}$ variation) for two or more measurements (5-10 min) were accepted for this study. Intracellular chloride was estimated from reversal potentials using the Nernst equation. For simplicity, we assume 100\% of current through the $\mathrm{GABA}_{\mathrm{A}}$ receptor was carried by $\mathrm{Cl}^{-}$and a chloride activity coefficient of 0.76 (Robinson and Stokes, 1959).

On-cell measurement of membrane potential. During a recording in the on-cell configuration, the patch of membrane within the pipette is exposed to a potential difference equal to the membrane potential $\left(\mathrm{V}_{\text {cell }}\right)$ minus the pipette command potential $\left(\mathrm{V}_{\text {patch }}=\mathrm{V}_{\text {cell }}-\mathrm{V}_{\text {pipette }}\right)$. Potassium channels within the pipette can be manipulated by varying the pipette potential and the reversal of current through these channels $\left(\mathrm{E}_{\mathrm{K}}\right)$ used to estimate membrane potential (Fricker et al., 1999; Verheugen et al., 1999; DeFazio et al., 2002). This method assumes that the concentration of potassium in the cell is similar to that in the pipette solution resulting in a reversal potential for potassium $\left(\mathrm{E}_{\mathrm{K}}\right)$ near zero. After establishing the on-cell configuration in the presence of $0.5 \mu \mathrm{M}$ TTX, inactivation of potassium channels was removed by setting $\mathrm{V}_{\text {pipette }}$ to $100 \mathrm{mV}$ 
for $60 \mathrm{~ms}\left(\mathrm{~V}_{\text {patch }} \sim-150 \mathrm{mV}\right.$, assuming $\left.-50 \mathrm{mV} \mathrm{V}_{\text {cell }}\right)$. Voltagedependent channels were then activated by ramping the pipette voltage from $100 \mathrm{mV}$ to $-150 \mathrm{mV}\left(\mathrm{V}_{\text {patch }} \sim-150\right.$ to $200 \mathrm{mV}$ ) over $30 \mathrm{~ms}$. During the voltage ramp, potassium channels are opened and generate an initial inward current followed by an outward current. Leak correction was applied by subtracting a linear fit of the current during the ramp before the activation of potassium currents. The ramp potential at which the leak corrected current crosses $0 \mathrm{pA}$ reflects the membrane potential of the cell. Accurate assessment of $\mathrm{V}_{\text {cell }}$ relies on the concentration of intracellular potassium, estimated to be $\sim 150 \mathrm{~mm}$. Although the concentration of intracellular potassium in AVPV and arcuate nucleus kisspeptin neurons has not yet been determined, a difference of $15 \mathrm{~mm}$ results in an offset of only $5 \mathrm{mV}$ (Fricker et al., 1999; Verheugen et al., 1999). Such an offset would not affect the relative difference in membrane potential attributable to GABA action, as the relationship was linear over the physiological range of membrane potentials examined (see Fig. 2). To assess the effect of rapid GABA, we delivered a control ramp to estimate the resting membrane potential, applied GABA, then immediately delivered another ramp to estimate the membrane potential response to GABA (total duration of voltage protocol including both ramps was $400 \mathrm{~ms}$; see Fig. 2).

Voltage-clamp recordings of GABAergic transmission. Whole-cell voltage-clamp recordings of GABAergic spontaneous postsynaptic currents (sPSCs) were obtained at $-60 \mathrm{mV}$ using the high chloride internal and in the presence of glutamatergic NMDA and AMPA receptor antagonists, APV $(20 \mu \mathrm{M})$ and CNQX $(10 \mu \mathrm{M})$. GABA miniature postsynaptic currents (mPSCs) were recorded with the addition of TTX (1 $\mu \mathrm{M})$. Series resistance ( $\angle 20 \mathrm{M} \Omega,<20 \%$ change during the recording period) and the passive properties of the neuron (input resistance $>300 \mathrm{M} \Omega$, membrane capacitance stable, and holding current absolute value $<100 \mathrm{pA}$ ) were monitored every $2 \mathrm{~min}$ using a $20 \mathrm{~ms}, 5 \mathrm{mV}$ hyperpolarizing voltage step from $-60 \mathrm{mV}$; our algorithm for determining these values discards traces with synaptic activity during this protocol. Input resistance values reported were pooled from sPSC and mPSC recordings in each experimental group. Membrane current at $-60 \mathrm{mV}$ was recorded in $2 \mathrm{~min}$ swathes. Every detected event was visually confirmed using custom software (Sullivan et al., 2003). Superimposed events were measured from each event's baseline for amplitude; such events were excluded from analysis of event kinetics and fluctuation analysis. Frequency is reported as the total number of events detected divided by the duration of the swathe (2 min). Amplitude is reported as the mean amplitude of all events. To evaluate receptor saturation, $1 \mu \mathrm{M}$ diazepam was bath applied during a subset of GABA mPSC recordings. Input resistance was measured at $-60 \mathrm{mV}$ using a $20 \mathrm{~ms},-5 \mathrm{mV}$ voltage step.

Postsynaptic receptor saturation assay. We tested the hypothesis that increasing the apparent affinity of the $\mathrm{GABA}_{\mathrm{A}}$ receptors increases the amplitude of mPSCs (for a recent review and discussion, see Barberis et al., 2011). If postsynaptic receptors are saturated, increasing apparent affinity cannot affect amplitude because all receptors are already occupied. To accomplish this, we bath applied the benzodiazepine agonist diazepam $(1 \mu \mathrm{M})$ while recording consecutive 2 min swathes of GABA PSCs and monitoring recording properties (Defazio and Hablitz, 1998; Perrais and Ropert, 1999). To determine whether diazepam increased mPSC amplitude, we compared the mPSC amplitude distributions obtained under control conditions and in the presence of diazepam using the Kolmogorov-Smirnov test ( $p<0.01$ considered significant). To select events for this analysis, a minimum amplitude of $50 \mathrm{pA}$ was imposed as the next analysis (peak-scaled nonstationary fluctuation analysis [NSFA]; see below) was performed only on mPSCs that were clearly isolated from other mPSCs and easily distinguished from the baseline. We use the term apparent affinity to describe the effect of diazepam on $\mathrm{GABA}_{\mathrm{A}}$ Rs because the detailed mechanisms of action of diazepam remain elusive, and the traditional mechanism of diazepam increasing "receptor affinity" may not be the only consequence of activation of the benzodiazepine site (e.g., Barberis et al., 2011; Gielen et al., 2012). In the nonstationary noise analysis results from the arcuate nucleus (see Fig. 6), diazepam increased the number of channels in association with increased amplitude and full-width at half-maximum of the macroscopic PSCs.
This is consistent with an increase in apparent affinity as at least one component of diazepam's action at nonsaturated synapses.

NSFA. In a subset of recordings that met stringent stability criteria and with sufficient numbers $(>50)$ of temporally isolated PSCs, peak-scaled NSFA was performed as described previously (Hartveit and Veruki, 2007). Briefly, GABAergic mPSCs $>50 \mathrm{pA}$ and occurring in isolation from others were aligned by the maximum rate-of-rise and averaged to generate the mean current $\left(\mathrm{I}_{\text {mean }}\right)$. $\mathrm{I}_{\text {mean }}$ was scaled to each individual event, subtracted from each event, and the difference squared to calculate variance. The mean variance of the decay phase of the mPSCs was plotted as a function of the averaged current amplitude and fitted with a parabola: variance $=\mathrm{i} \mathrm{I}_{\text {mean }}-\mathrm{I}_{\text {mean }}{ }^{2} / \mathrm{N}$, where $\mathrm{i}$ is the single-channel current, $\mathrm{I}_{\text {mean }}$ is the average GABAergic mPSC, and $\mathrm{N}$ is the number of channels. These properties were obtained from at least 50 events per recording. In suitably stable recordings, these properties were repeatedly calculated over time to assess the effect of diazepam. Single-channel current was divided by the driving force to yield an estimate of the single-channel conductance, g. To validate this approach, mPSC recordings were obtained from cortical neurons under the same mPSC recording conditions reported above $(n=2)$ for comparison with published values estimated from GABA PSCs (Perrais and Ropert, 1999). Consistent with previous studies, mean unitary conductance in cortical neurons was $24.2 \mathrm{pS}$ under control conditions, regardless of holding potential, and the mean number of channels was 23.3. It is important to note that, although fluctuation analysis is a useful tool that provides indirect estimates of singlechannel properties, there are caveats. NSFA is applied to macroscopic currents and relies on basic mechanistic assumptions about kinetics of transitions between multiple states of the ligand-gated receptor/channel complex (e.g., on- and off-rates of binding, activation, and gating kinetics). This approach suffers from what has been referred to as the "binding-gating problem"; specifically, that it is difficult to differentiate binding of the agonist and gating of the receptor, and these two states must affect one another (Colquhoun and Sakmann, 1998; Colquhoun, 1998, 2006). Traditional terms, such as "affinity" and "efficacy," are difficult to establish experimentally (e.g. Colquhoun, 2006). Furthermore, direct assessment of synaptic $\mathrm{GABA}_{\mathrm{A}}$ receptor single-channel properties is complicated by the existence of extrasynaptic receptors consisting of potentially different subunit composition and, thus, different biophysical properties from the synaptic receptors studied here using NSFA. Detailed single-channel biophysical characterization of synaptic $\mathrm{GABA}_{\mathrm{A}}$ receptors is therefore beyond the scope of the current work.

Statistics. Data are reported as mean \pm SEM. Data were normally distributed; thus, comparisons among groups were made by two-way ANOVA with Fisher's Least Significant Difference (LSD) post hoc comparisons, or unpaired two-tailed Student's $t$ test using Graphpad Prism 6. Repeated-measures ANOVA with Holm-Sidak post hoc correction for multiple comparisons was used in comparing the on-cell measurement of membrane potential $(\mathrm{OCVm})$ measurements of the response to GABA. $p<0.05$ was accepted as significant, except $p<0.01$ used for Kolmogorov-Smirnov tests for changes in GABA PSC parameter distributions acquired during diazepam experiments. Statistical tests, $p$ values, specific $t$ values, and degrees of freedom (reported as $t_{\mathrm{df}}$ ) derived from $t$ tests or Fisher's LSD after ANOVA are reported in the text. $\mathrm{F}_{\mathrm{DFn}, \mathrm{DFd}}$ values from ANOVA are reported in Table 4 or in the text.

\section{Results}

Table 1 contains the number of recordings and animals for each group for the primary types of recordings presented below; $n$ is also included in the figure legend. No more than three cells were recorded from a single animal.

\section{Reversal potential for current through the $\mathrm{GABA}_{\mathrm{A}}$ receptor $\left(\mathrm{E}_{\mathrm{GABA}}\right)$ in kisspeptin neurons is not modulated by estradiol or time of day}

Gramicidin perforated patch recordings were obtained to examine $\mathrm{E}_{\mathrm{GABA}}$ in both hypothalamic kisspeptin populations as a function of estradiol and time of day. GABA was locally applied via pressure application $20-50 \mu \mathrm{m}$ from the soma during a series of 
Table 1. Number of recordings and animals in each experimental group ${ }^{a}$

\begin{tabular}{llclll}
\hline & Gramicidin & OCVm & sPSCs & mPSCs (NSFA) & Diazepam (NSFA) \\
\hline Arcuate nucleus & & & & & \\
OVX AM & $5 / 4$ & $14 / 12$ & $10 / 6$ & $10 / 6$ & $2 / 2(1)$ \\
OVX + E AM & $8 / 6$ & $10 / 7$ & $13 / 8$ & $14 / 7$ & $2 / 2(2)$ \\
OVX PM & $4 / 4$ & $7 / 6$ & $14 / 10$ & $8 / 11(8)$ & \\
OVX + EPM & $7 / 6$ & $10 / 9$ & $13 / 8$ & $12 / 8(6)$ & $2 / 2(2)$ \\
AVPV & & & & & \\
OVX AM & $4 / 4$ & $9 / 7$ & $18 / 12$ & $11 / 9$ & \\
OVX + E AM & $5 / 3$ & $8 / 6$ & $7 / 5$ & $7 / 5$ & $2 / 2(1)$ \\
OVX PM & $5 / 3$ & $10 / 7$ & $13 / 10$ & $11 / 8(5)$ & \\
OVX + EPM & $5 / 3$ & $9 / 5$ & $9 / 5$ & $8 / 6(4)$ & $1 / 1(1)$ \\
\hline
\end{tabular}

${ }^{a}$ Data are number of recordings/number of mice. Number in parenthesis indicates number of recordings analyzed with NSFA. OCVm, On-cell measurements of membrane potential.

membrane potential steps, and the reversal potential for the GABA-induced current $\left(\mathrm{E}_{\mathrm{GABA}}\right)$ was calculated after correction for series resistance (Fig. $1 A, B$ ). $\mathrm{E}_{\mathrm{GABA}}$ was not affected by either estradiol treatment or time of day within a population (Fig. $1 C$ ). Because of this, all cells from each anatomical region were pooled to test for differences between the arcuate nucleus and AVPV kisspeptin neuron populations. $\mathrm{E}_{\mathrm{GABA}}$ was more depolarized in arcuate nucleus than AVPV neurons $(-55.5 \pm 2.6 \mathrm{mV}$ vs $68.8 \pm$ $1.9 \mathrm{mV} ; p<0.01$, unpaired two-tailed $t$ test, $t_{(40)}=3.8$, total $n=$ 24 arcuate nucleus, $n=19$ AVPV). Consequently, the estimated intracellular chloride concentration was higher $(p<0.01$, unpaired two-tailed $t$ test, $t_{(40)}=3.3$ ) in arcuate nucleus kisspeptin neurons $(14.7 \pm 1.6 \mathrm{~mm})$ than AVPV neurons $(8.2 \pm 0.6 \mathrm{~mm})$.

Both baseline membrane potential and response to GABA differ in arcuate nucleus versus AVPV kisspeptin neurons

The physiological response of a cell to activation of the $\mathrm{GABA}_{\mathrm{A}}$ receptor depends on $\mathrm{E}_{\mathrm{GABA}}$, the membrane potential at the time of receptor activation and interactions with other intrinsic conductances (voltage-gated and non-voltage-gated) in the postsynaptic cell. To examine the response to GABA, estimates of membrane potential were obtained in the on-cell configuration, which maintains native intracellular chloride levels. OCVm relies on the reversal potential of voltage-gated potassium currents in the on-cell patch (Fricker et al., 1999; Verheugen et al., 1999). Figure $2 A$ shows the voltage protocol used, and Figure $2 B$ shows representative responses in arcuate nucleus versus AVPV neurons. This approach was validated by evaluating the relationship between the membrane potential estimated with OCVm and that directly measured by whole-cell current-clamp by making simultaneous on-cell and whole-cell recordings of the same cell (Fig. $2 C)$. A consistent linear relationship was observed $\left(R^{2}=0.84\right.$, $x$-intercept $=7.6 \pm 3.9 \mathrm{mV}$, slope $=1.1 \pm 0.1, n=4)$.

We used OCVm to assess baseline membrane potential and the membrane potential during the response to GABA. In arcuate nucleus kisspeptin neurons, OCVm revealed that baseline membrane potential was unchanged by time of day or estradiol (Table 2; Fig. $2 D$ ). The membrane potential during GABA application was robustly depolarized relative to the baseline membrane potential in neurons from OVX $+\mathrm{E}$ treated mice, achieving values near the $\mathrm{E}_{\mathrm{GABA}}$ observed during gramicidin perforated patch experiments (Fig. 2D, dashed lines). In arcuate nucleus kisspeptin neurons from OVX mice not treated with estradiol, GABA did not change the membrane potential from baseline despite baseline being hyperpolarized relative to $\mathrm{E}_{\mathrm{GABA}}$. This suggests a shunting effect attributable to changes in other intrinsic currents. Consistent with this, whole-cell recordings revealed that input resistance in arcuate nucleus neurons from estradiol-treated mice was higher than that in neurons from OVX mice, indicating a change in membrane conductance (OVX AM $659 \pm 69 \mathrm{M} \Omega, n=$ 17; OVX +E AM $1070 \pm 94 \mathrm{M} \Omega, n=16$; OVX PM $673 \pm 55 \mathrm{M} \Omega$, $n=23$; OVX + E PM $809 \pm 61 \mathrm{M} \Omega, n=24, p<0.01$, two-way ANOVA, steroid, $\left.F_{(1,76)}=15.5\right)$. The change in membrane potential ( $\Delta=\mathrm{GABA}$ - baseline; Fig. $2 E$ ) further illustrates the blunted membrane potential depolarization induced by GABA in arcuate nucleus kisspeptin neurons in slices from OVX versus $\mathrm{OVX}+\mathrm{E}$ mice.

In AVPV kisspeptin neurons, OCVm revealed both time of day- and estradiol-dependent effects on membrane potential at baseline and during GABA application. In the AM, GABA robustly hyperpolarized AVPV kisspeptin neurons from both OVX and $\mathrm{OVX}+\mathrm{E}$ mice to membrane potentials near $\mathrm{E}_{\mathrm{GABA}}$ (Fig. 2; Table 2). In contrast, in the PM, the membrane potential during GABA application was hyperpolarized relative to baseline only in neurons from OVX $+\mathrm{E}$ mice. Interestingly, the loss of membrane potential response to GABA in neurons from OVX mice in the PM was attributed to a hyperpolarization of baseline membrane potential to values near $\mathrm{E}_{\mathrm{GABA}}$. No differences in input resistance were observed for AVPV neurons among the different treatment groups (OVX AM $827 \pm 59 \mathrm{M} \Omega, n=23$; OVX +E AM $652 \pm 83 \mathrm{M} \Omega, n=13$; OVX PM $785 \pm 52 \mathrm{M} \Omega, n=$ 21; OVX + E PM $848 \pm 83 \mathrm{M} \Omega, n=15)$. The shift in baseline effectively neutralizes the electrochemical driving force for chloride flux through the $\mathrm{GABA}_{\mathrm{A}}$ receptor channel, as shown by the lack of change in membrane potential in response to GABA (Fig. $2 E)$.

\section{GABAergic transmission to arcuate nucleus kisspeptin neurons is modulated by time of day and estradiol}

We next investigated GABAergic synaptic transmission to arcuate nucleus and AVPV kisspeptin neurons as a function of both estradiol and time of day. To control for the postsynaptic variability in cell membrane potential and chloride homeostasis, voltage-clamp recordings were performed at $-60 \mathrm{mV}$ using a high chloride internal solution and isolated the resulting inward $\mathrm{GABA}_{\mathrm{A}}$ receptor-mediated PSCs by blocking ionotropic glutamate receptors.

Representative recordings of spontaneous GABAergic transmission to arcuate nucleus kisspeptin neurons are shown in Figure $3 A$. In cells from OVX mice, sPSC frequency was higher in the PM than in the AM (Fisher's LSD, $p<0.02, t_{(46)}=2.5$, summarized in Table 3; Fig. $3 C$ ). In contrast, in cells from OVX $+\mathrm{E}$ mice, sPSC frequency did not vary with time of day, suggesting that estradiol may activate GABAergic afferents during the AM. In cells from OVX mice, sPSC amplitude was lower in the PM than the AM (Fisher's LSD, $p<0.02, t_{(46)}=2.6$; Fig. $3 E$ ). As with sPSC frequency, sPSC amplitude did not depend on time of day in cells from OVX $+\mathrm{E}$ mice. Estradiol did, however, reduce (Fisher's LSD, $\left.p<0.01, t_{(46)}=3.6\right)$ sPSC amplitude in the AM relative to that in neurons from OVX mice.

Differences in frequency of sPSCs can be attributable to changes in the presynaptic action potential firing pattern and/or structural changes in the number of presynaptic release sites. To begin to distinguish between activity-dependent and structural changes, presynaptic activity was blocked with TTX and mPSCs were recorded (Fig. 3B). In general, mPSC frequency was less than sPSC frequency compared within a steroid/time of day condition (one-way ANOVA, $F_{(7,86)}=3.9$, post hoc Fisher's LSD, $p<$ $0.05, t_{(86)}>2.3$, except OVX AM; see below). This suggests substantial presynaptic activity in the coronal slice orientation, in contrast to a previous study in $\mathrm{GnRH}$ neurons, which showed 
that presynaptic activity was preserved in the sagittal slice preparation but not coronal (Christian and Moenter, 2007). In the arcuate nucleus OVX AM group, however, there was no difference between sPSC and mPSC frequency, indicating minimal presynaptic activity during the $\mathrm{AM}$ in OVX mice, again suggesting that estradiol activates GABAergic afferents to these neurons in the AM. Even after presynaptic activity was blocked, the PM increase in frequency of $\mathrm{GABA}_{\mathrm{A}}$ receptormediated events persisted in slices from OVX mice. Specifically, in arcuate kisspeptin neurons from OVX mice, mPSC frequency was greater in the PM than in the AM (Fisher's LSD, $p<0.02, t_{(40)}=$ 2.7; Fig. $3 D$ ). This indicates that a component of the time of day change in sPSC frequency observed in this group is likely attributable to presynaptic increases in the number of release sites and/or the probability of release. No time of day effect on mPSC amplitude was detected in arcuate nucleus kisspeptin neurons. In contrast, estradiol treatment reduced the mPSC amplitude in both the AM and PM (Fisher's LSD, $p<0.01$, AM $t_{(40)}=3.1, \mathrm{PM} t_{(40)}=4.8$; Fig. $3 F$ ).

In contrast to arcuate nucleus PSC frequency, comparison of sPSC with mPSC amplitudes within a steroid/time of day group revealed no differences. This suggests that action potentialdriven release (sPSCs) and random release from individual release sites (mPSCs) appear to activate the same number of receptors. Although there are multiple mechanisms that could underlie the lack of difference between sPSC and mPSC amplitude, we performed studies to distinguish between two extremes. At the one extreme, the amount of GABA released from a single release site during a mPSC greatly exceeds the number of postsynaptic receptors (i.e., a single "miniature" release event saturates available $\mathrm{GABA}_{\mathrm{A}}$ receptors). In this scenario, postsynaptic receptors are saturated; thus, additional GABA release driven by action potentials has no effect on amplitude. At the other extreme, the amount of GABA released is low compared with the number of receptors for both miniature and action potential driven GABA PSCs. In this case, the number of receptors exceeds the GABA available after either miniature or action potential driven release (i.e., receptors are not saturated).

\section{Assessment of postsynaptic receptor saturation in arcuate kisspeptin neurons}

To distinguish between these two possible explanations of no effect of TTX on GABA PSC amplitude, we tested whether postsynaptic $\mathrm{GABA}_{\mathrm{A}}$ receptors are saturated during $\mathrm{mPSC}$ using diazepam, a benzodiazepine agonist that increases the apparent affinity of the $\mathrm{GABA}_{\mathrm{A}} \mathrm{R}$ for $\mathrm{GABA}$. Figure $5 A$ shows representative average and normalized average traces from arcuate nucleus kisspeptin neurons before and during diazepam treatment. As expected, increasing $\mathrm{GABA}_{\mathrm{A}}$ receptor affinity with diazepam prolonged the decay phase of mPSCs relative to prediazepam control levels measured as the full-width-at-half-maximum but had no effect on presynaptic mPSC features, such as frequency or interval (see Fig. 5B). This effect serves as a positive control for the actions of the benzodiazepine agonist (e.g., Defazio and Hablitz,
1998). In 5 of 6 arcuate nucleus mPSC recordings, diazepam increased mPSC amplitude (Kolmogorov-Smirnov test, $p<$ 0.01 ; see Fig. $5 B$ ), consistent with an increased number of receptors activated by GABA attributable to the increase in $\mathrm{GABA}_{\mathrm{A}} \mathrm{R}$ apparent affinity in the presence of diazepam.

\section{Peak-scaled fluctuation analysis of arcuate nucleus GABA mPSCs}

To assess the number of receptors activated by mPSCs, we used peak-scaled NSFA of GABA mPSCs (De Koninck and Mody, 1994; Hartveit and Veruki, 2007). This statistical analysis of the variance of the decay phase of mPSCs yields an estimate of the conductance of the channel ( $\mathrm{g}$ ) and the number of receptor/ channels $(\mathrm{N})$. Figure $6 A$ shows a representative individual mPSC from an arcuate nucleus kisspeptin neuron (black) and the scaled mPSC average (red, normalized to the amplitude of the individual mPSC) for that cell, as well as the difference between these traces (blue). Figure $6 \mathrm{~B}$ shows the relationship of variance (difference squared) and amplitude of the average $\mathrm{mPSC}\left(\mathrm{I}_{\text {mean }}\right)$ as a function of time. The variance is minimal at the peak of the mean trace (see Fig. 6B, vertical dashed line) (De Koninck and Mody, 1994). In a very simplified model in which one considers only open versus closed states, this can be attributed to most channels being open upon onset of the GABAergic stimulation before they begin fluctuating between open and closed states during the decay of the PSC. Variance was plotted as a function of $\mathrm{I}_{\text {mean }}$ and fit with a parabolic function (see Fig. $6 C$ ). To avoid oversampling during the long decay phase of the mPSC, variance was binned by amplitude (Hartveit and Veruki, 2007). We estimated $g$ and $\mathrm{N}$ in a subset of mPSC recordings from arcuate nucleus kisspeptin neurons that met the stringent stability criteria for NSFA, and compared values before and during diazepam (see Fig. 6D). Diazepam increased the number of channels (baseline $36.3 \pm 34.8$ vs diazepam $57.2 \pm 11.3$; paired $t$ test, $p<0.05, t_{(4)}=3.4$ ); although there was a diminution of $g$ (baseline $80.0 \pm 8.2 \mathrm{pS}$ vs diazepam $63.9 \pm 8.1 \mathrm{pS}$ ), this is attributed to slightly higher series 
A

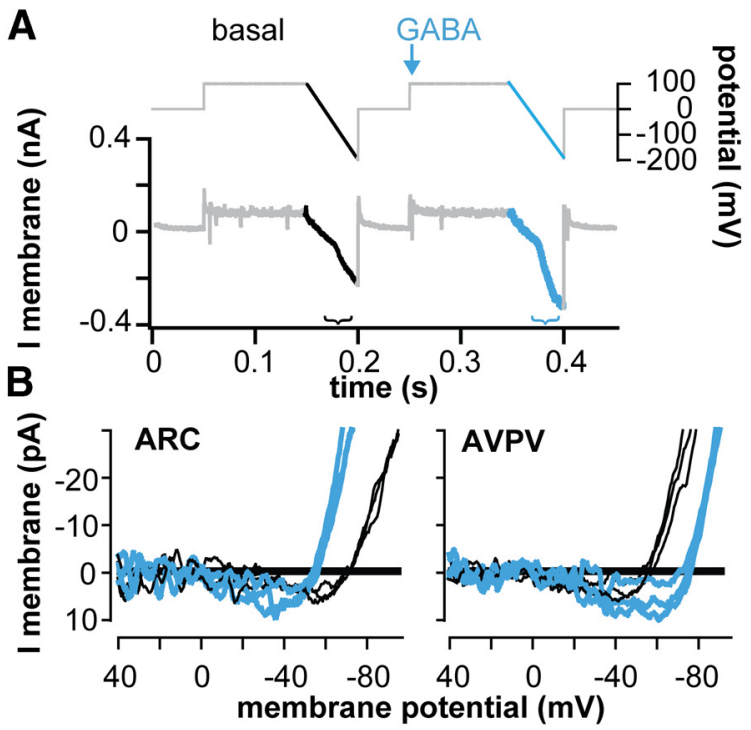

C

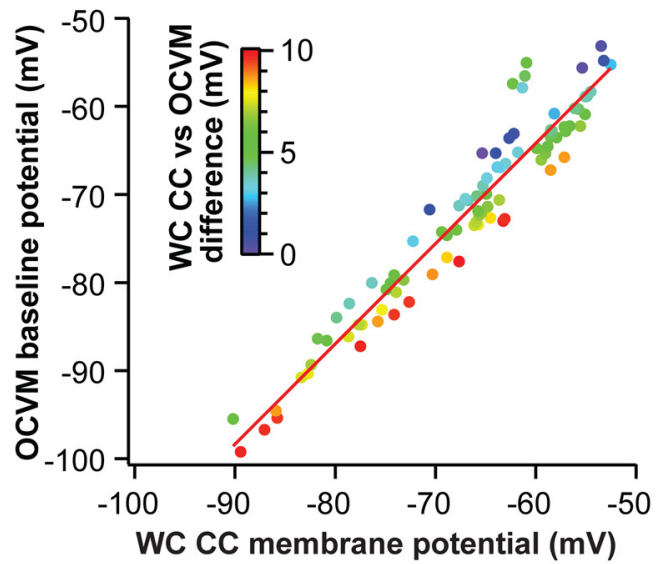

D
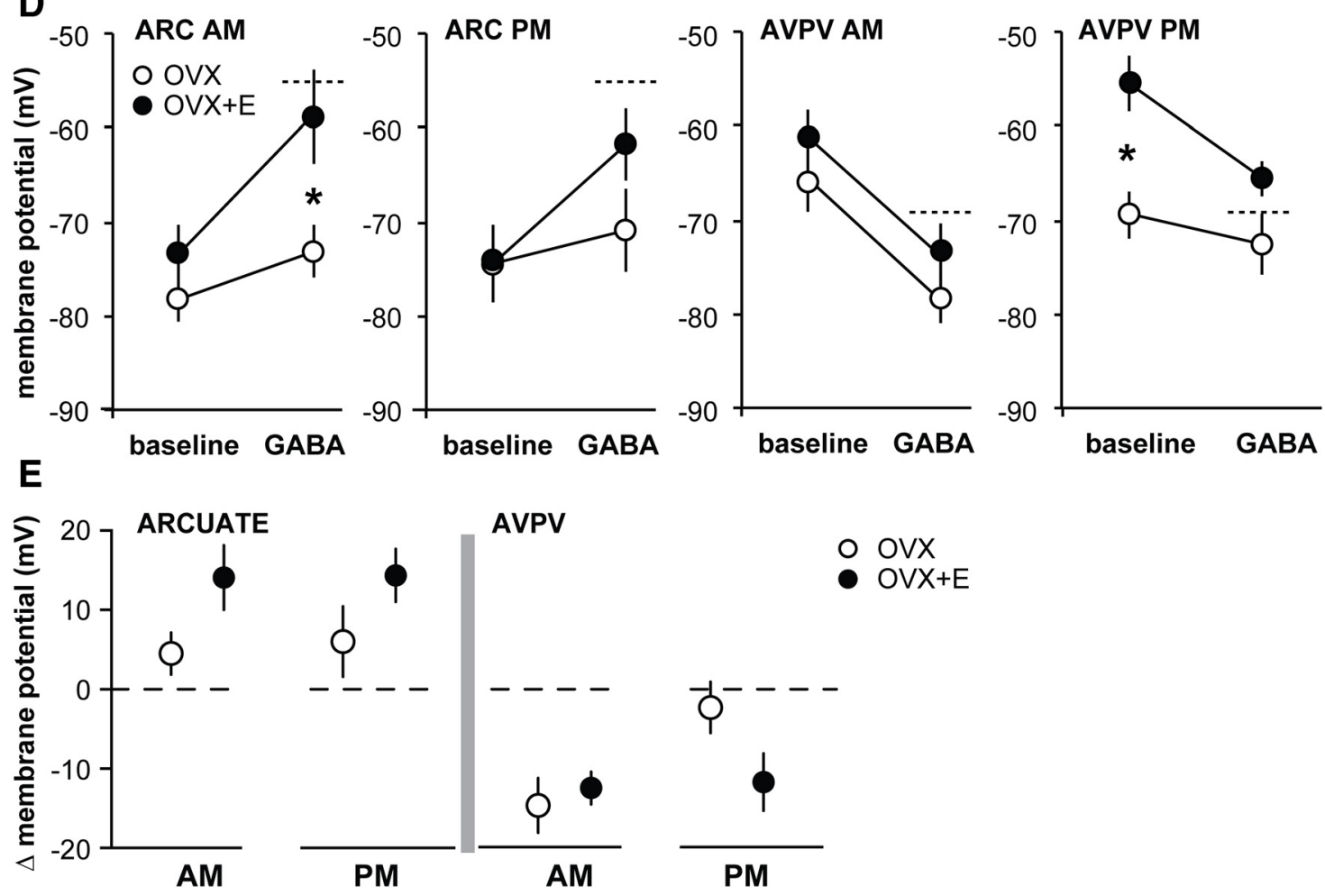

Figure 2. Response to GABA differs with estradiol, time of day, and kisspeptin neuronal population. $A, 0 C V m$ recording methodology. Top, Voltage protocol. Arrow indicates timing of local GABA application. B, Leak-subtracted OCVm traces during baseline (black) and GABA (blue) illustrate representative depolarizing responses in arcuate nucleus (ARC) and hyperpolarizing responses in AVPV kisspeptin neurons. $\boldsymbol{C}$, Plot of membrane potential monitored by simultaneous whole-cell current-clamp (WC CC) and OCVm recordings of the same cell. Colors represent the absolute value of the difference between the WCCC value and the $0 C V \mathrm{~m}$ value (scale inset). $\boldsymbol{D}$, Mean \pm SEM membrane potential during baseline and GABA application for each experimental group. Dotted line indicates $\mathrm{E}_{\mathrm{GABA}}$ measured in Figure 1. ${ }^{*} p<0.05$, OVX versus OVX +E. N: arcuate OVX AM 14/12, OVX+E AM 10/7, OVX PM 7/6, OVX+E PM 10/9; AVPV OVX AM 9/7, 0VX+E AM 8/6, OVX PM 10/7, 0VX+E PM 9/5. $E$, Mean \pm SEM change $(\Delta)$ in membrane potential for each group. Dashed line indicates zero change in response to GABA.

Table 2. OCVm measurements of baseline membrane potential and membrane potential achieved during GABA

\begin{tabular}{|c|c|c|c|c|c|c|}
\hline & \multicolumn{3}{|l|}{$\mathrm{AM}$} & \multicolumn{3}{|l|}{ PM } \\
\hline & Baseline (mV) & GABA (mV) & $\Delta(\mathrm{mV})$ & Baseline (mV) & GABA (mV) & $\Delta(\mathrm{mV})$ \\
\hline \multicolumn{7}{|c|}{ Arcuate nucleus } \\
\hline ovx & $-78.4 \pm 2.3$ & $-73.3 \pm 2.8^{*}$ & $4.8 \pm 2.8$ & $-74.5 \pm 4.2$ & $-70.9 \pm 4.5$ & $3.8 \pm 4.6$ \\
\hline \multicolumn{7}{|l|}{ AVPV } \\
\hline OVX & $-65.5 \pm 3.6$ & $-78.4 \pm 2.5$ & $-13.0 \pm 2.9$ & $-69.5 \pm 2.5^{*}$ & $-72.6 \pm 3.3$ & $-2.9 \pm 2.9$ \\
\hline $\mathrm{OVX}+\mathrm{E}$ & $-61.1 \pm 2.7$ & $-73.7 \pm 3.4$ & $-12.6 \pm 2.1$ & $-55.6 \pm 3.0$ & $-65.6 \pm 1.9$ & $-11.8 \pm 3.6$ \\
\hline
\end{tabular}

${ }^{*} p<0.05$, Fisher's LSD: arcuate GABA OVX AM versus OVX $+E$ AM, $t_{(74)}=3.3 ;$ AVPV baseline OVX PM versus OVX $+E P M, t_{(62)}=3.4$. 
A

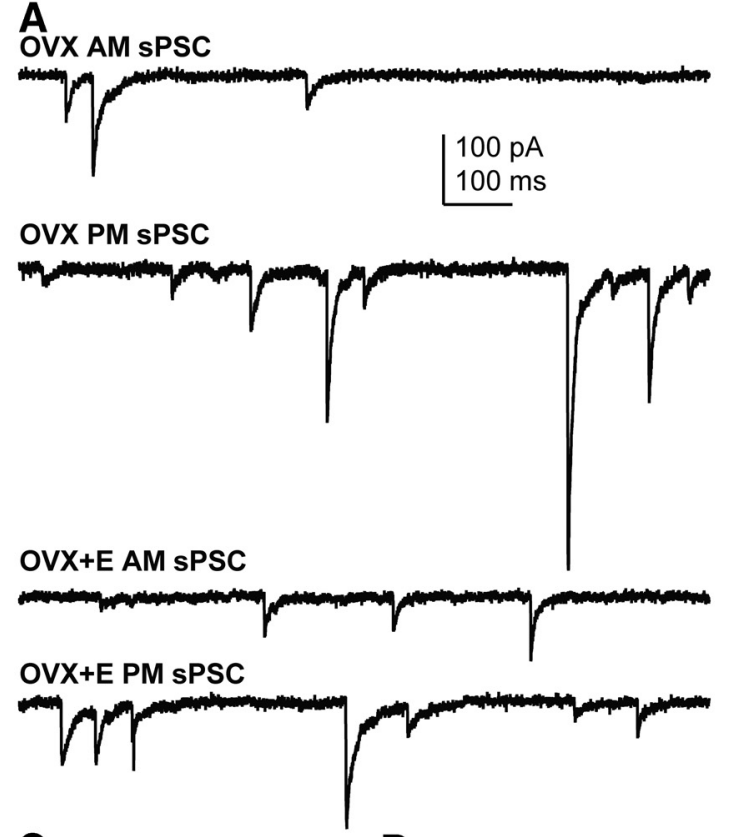

C

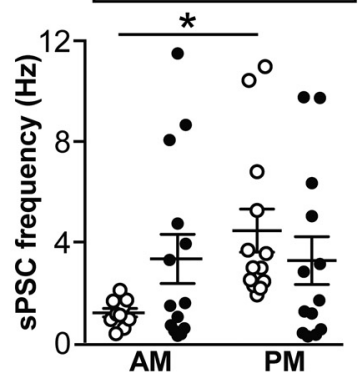

D

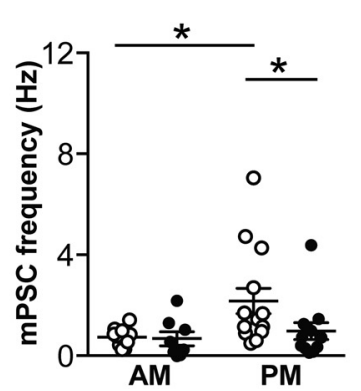

$B$

OVX AM mPSC

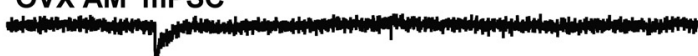

OVX PM mPSC

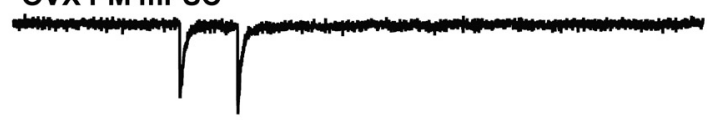

OVX+E AM MPSC

\section{OVX+E PM mPSC}

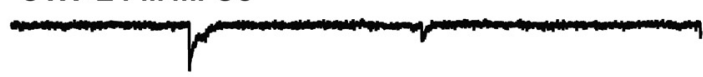

E

F

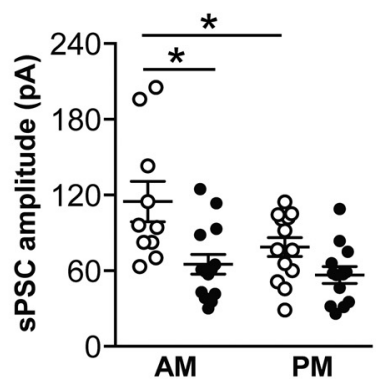

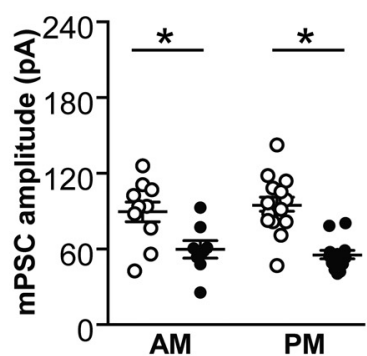

Figure 3. Regulation of GABAergic transmission to arcuate nucleus kisspeptin neurons by estradiol and time of day. $\boldsymbol{A}$, Representative traces illustrate sPSCs under the four experimental conditions. $\boldsymbol{B}$, Representative traces illustrate mPSCs recorded in the presence of TTX under the four experimental conditions. $(-\boldsymbol{F}$, Mean \pm SEM plus scatter plots of the mean sPSC frequency $(\boldsymbol{C})$, mPSC frequency $(\boldsymbol{D})$, sPSC amplitude $(\boldsymbol{E})$, and $\mathrm{mPSC}$ amplitude $(\boldsymbol{F}) .{ }^{*} p<0.05$. N is reported as the number of recordings/number of animals: arcuate GABA sPSC OVX AM 10/6, OVX+EAM 13/8, OVX PM 14/10, OVX+EPM 13/8; arcuate GABA mPSC OVX AM 10/6, OVX+E AM 14/7, OVX PM 8/11, 0VX+E PM 12/8.

Table 3. Properties of GABAergic PSCs

\begin{tabular}{clllll}
\hline & \multicolumn{2}{l}{ Frequency $(\mathrm{Hz})$} & & Amplitude $(\mathrm{pA})$ & \\
\cline { 2 - 3 } \cline { 5 - 6 } & AM & PM & & AM & PM \\
\hline Arcuate sPSCs & & & & & \\
OVX & $1.2 \pm 0.2^{* *}$ & $4.4 \pm 0.9$ & & $-115.5 \pm 16.0^{\dagger}$ & $-79.4 \pm 7.5$ \\
OVX $+\mathrm{E}$ & $3.3 \pm 1.0$ & $3.2 \pm 0.9$ & $-65.8 \pm 7.8$ & $-57.2 \pm 6.5$ \\
mPSCS & & & & \\
OVX & $0.8 \pm 0.1^{* *}$ & $2.2 \pm 0.5^{*}$ & $-89.7 \pm 8.0^{*}$ & $-94.7 \pm 6.2^{*}$ \\
OVX $+\mathrm{E}$ & $0.7 \pm 0.2$ & $1.0 \pm 0.3$ & $-59.6 \pm 6.3$ & $-55.1 \pm 3.4$ \\
AVPV sPSC & & & & \\
OVX & $7.0 \pm 0.7^{* *}$ & $12.3 \pm 1.7^{*}$ & & $-66.6 \pm 6.5$ & $-74.2 \pm 5.0^{*}$ \\
OVX $+\mathrm{E}$ & $7.2 \pm 1.2$ & $7.8 \pm 1.5$ & $-61.6 \pm 6.1^{* *}$ & $-104.2 \pm 20.6$ \\
mPSC & & & & \\
OVX & $1.8 \pm 0.3^{* *}$ & $4.9 \pm 0.9$ & & $-77.6 \pm 10.2$ & $-78.6 \pm 7.5$ \\
OVX $+\mathrm{E}$ & $3.3 \pm 0.5$ & $3.3 \pm 0.7$ & $-89.4 \pm 2.6$ & $-75.2 \pm 6.9$ \\
\hline
\end{tabular}

${ }^{*} p<0.05$ versus $0 \mathrm{VX}+\mathrm{E}_{i}^{*}{ }^{* *} p<0.05$ versus $\mathrm{PM} ;{ }^{\dagger} p<0.05$ versus $0 \mathrm{VX}+\mathrm{E}$ and $\mathrm{PM}$.

resistance during the diazepam portion of the recordings and is not likely to be of biological importance.

We next estimated $\mathrm{g}$ and $\mathrm{N}$ in arcuate nucleus kisspeptin neurons recorded in the PM from either OVX or OVX+E mice. We detected no difference in conductance $(60.6 \pm 10.6 \mathrm{pS}$ vs $54.5 \pm$ $5.3 ; p>0.3$; see Fig. $6 E$ ). The mean number of channels activated by a single release site, however, was decreased in cells from
OVX+E PM versus OVX PM group (42.0 \pm 5.0 vs $25.1 \pm 3.1$; Fig. $6 E$; unpaired two-tailed $t$ test, $\left.p<0.02, t_{(11,12)}=2.9\right)$. Together, these data demonstrate that postsynaptic $\mathrm{GABA}_{\mathrm{A}}$ receptors are not saturated by single release site and that a decrease in the number of receptors bound seems to underlie the estradiolinduced decrease in mPSC amplitude observed in arcuate nucleus kisspeptin GABA mPSCs.

GABAergic transmission to AVPV kisspeptin neurons is modulated by time of day and estradiol

In AVPV kisspeptin neurons (Fig. 4), sPSC frequency was increased in the PM relative to the AM in cells from OVX mice (Fisher's LSD, $p<0.01, t_{(43)}=3.2$ ). In the PM, estradiol suppressed sPSC frequency compared with that in OVX mice (Fisher's LSD, $p<0.05, t_{(43)}=2.3$; Fig. $4 C$ ). sPSC amplitude was not affected by time of day in cells from OVX mice; however, estradiol increased the amplitude of sPSCs in the PM (OVX PM $<$ OVX+E PM, Fisher's LSD, $p<0.05, t_{(43)}=2.0$; Fig. $\left.4 E\right)$, and a time of day effect was detected in AVPV neurons from OVX $+\mathrm{E}$ mice (OVX $+\mathrm{E}$ AM $<$ OVX + E PM, Fisher's LSD, $p<0.02$, $\left.t_{(43)}=2.5\right)$. As in arcuate nucleus kisspeptin neurons, we recorded mPSCs in the presence of TTX to block neuronal activity. mPSC frequency was decreased relative to that of sPSCs in each time of day/steroid group (except OVX+E AM), again demon- 


\section{A ovx AM sPSC}

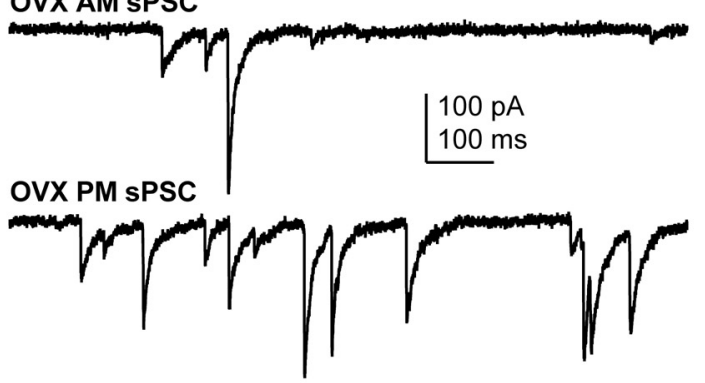

OVX+E AM sPSC

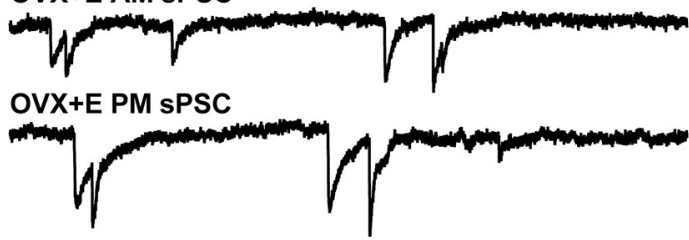

B

OVX AM mPSC

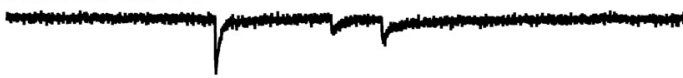

OVX PM mPSC

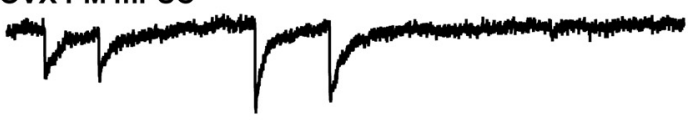

OVX+E AM mPSC

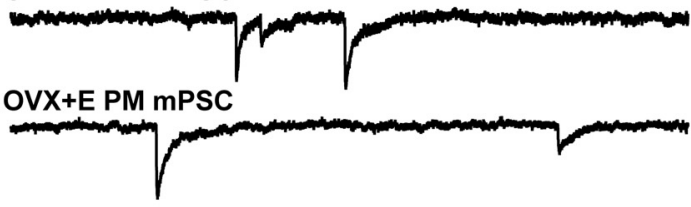

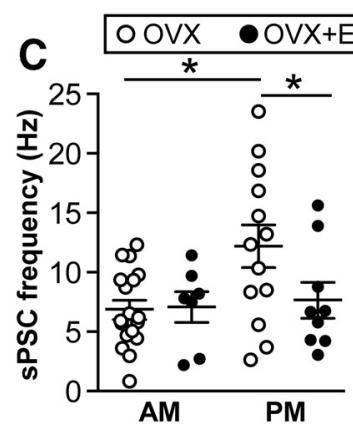
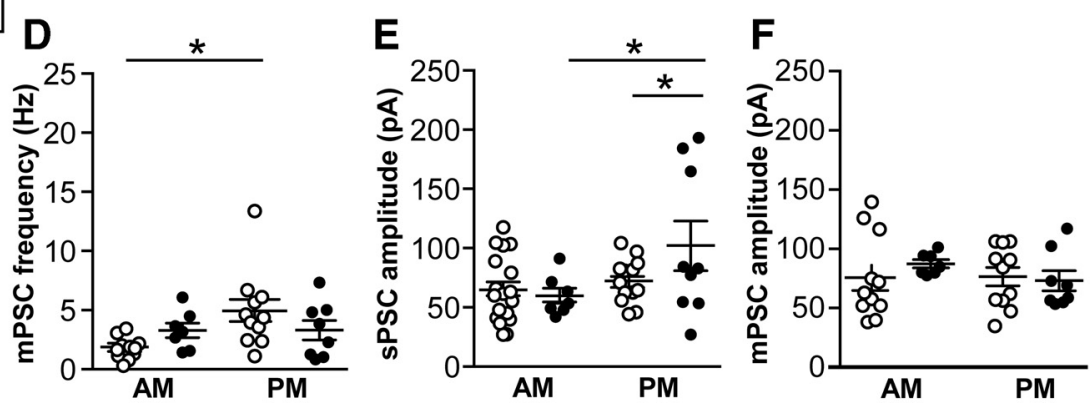

Figure 4. Regulation of GABAergic transmission to AVPV kisspeptin neurons by estradiol and time of day. $A$, Representative traces illustrate sPSCs under the four experimental conditions. $\boldsymbol{B}$, Representative traces illustrate mPSCs recorded in the presence of TTX under the four experimental conditions. $(-\boldsymbol{F}$, Mean \pm SEM plus scatter plots of the sPSC frequency (C), $\mathrm{mPSC}$ frequency (D), SPSC amplitude $(\boldsymbol{E})$, and $\mathrm{mPSC}$ amplitude $(\boldsymbol{F}) .{ }^{*} p<0.05$. N is reported as the number of recordings/number of animals: AVPV GABA sPSC OVX AM 18/12, OVX+E AM 7/5, OVX PM 13/10, OVX +E PM 9/5; AVPV GABA mPSC OVX AM 11/9, OVX+E AM 7/5, OVX PM 11/8, OVX+E PM 8/6.

Table 4. ANOVA $\mathrm{F}_{\mathrm{DFn}, \mathrm{DFd}}$ and significance

\begin{tabular}{|c|c|c|c|c|}
\hline \multirow[b]{2}{*}{ Two-way ANOVA } & \multicolumn{2}{|l|}{ GABA sPSCs } & \multicolumn{2}{|l|}{ GABA mPSCs } \\
\hline & Amplitude & Frequency & Amplitude & Frequency \\
\hline \multicolumn{5}{|l|}{ Arcuate } \\
\hline Time of day & $F_{(1,46)}=5.7^{*}$ & $F_{(1,46)}=3.4$ & $F_{(1,40)}=0.002$ & $F_{(1,40)}=4.6^{*}$ \\
\hline Interaction & $F_{(1,46)}=2.2$ & $F_{(1,46)}=3.6$ & $F_{(1,40)}=0.6$ & $F_{(1,40)}=2.0$ \\
\hline \multicolumn{5}{|l|}{ AVPV } \\
\hline Time of day & $F_{(1,43)}=5.6^{*}$ & $F_{(1,43)}=4.3^{*}$ & $F_{(1,33)}=0.5$ & $F_{(1,33)}=4.4^{*}$ \\
\hline Interaction & OCVm & & & \\
\hline RM ANOVA & Arcuate & AVPV & & \\
\hline Baseline - GABA & $F_{(1,37)}=28.1^{* * *}$ & $F_{(1,31)}=45.0^{* * *}$ & & \\
\hline \multicolumn{5}{|l|}{ Estradiol - } \\
\hline Time of day & $F_{(3,37)}=2.3$ & $F_{(3,31)}=3.9^{* *}$ & & \\
\hline
\end{tabular}

strating presynaptic activity in the coronal slice preparation ( $\mathrm{Ta}-$ ble 4; one-way ANOVA, $\left.F_{(7,72)}=9.2, p<0.05, t_{(72)}=2.5-4.9\right)$. In the absence of presynaptic activity, mPSC frequency was still greater in slices from OVX mice in the PM than in the AM (Fisher's LSD, $\left.p<0.01, t_{(33)}=3.3\right)$, similar to the arcuate nucleus kisspeptin neurons. Blocking presynaptic activity with TTX to record $\mathrm{mPSC}$ eliminated the difference observed in sPSC fre- quency in OVX PM versus OVX+E PM, suggesting that estradiol suppressed presynaptic action potential firing, as opposed to structural changes, such as the number of release sites. mPSC amplitude was not different among groups in AVPV kisspeptin neurons (Fig. $4 F$ ), nor were changes in amplitude observed within a time of day/ steroid treatment group when sPSC and mPSC amplitudes were directly compared for each group (Fig. $4 E$ vs Fig. $4 F$ ). 
A arcuate
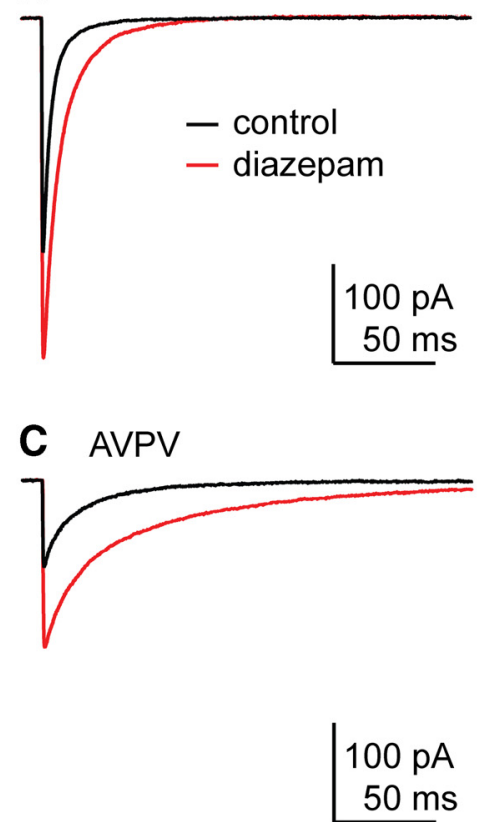

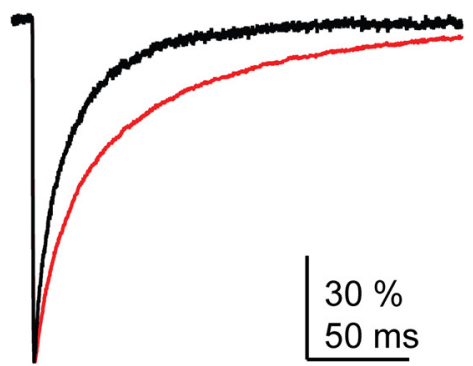

B

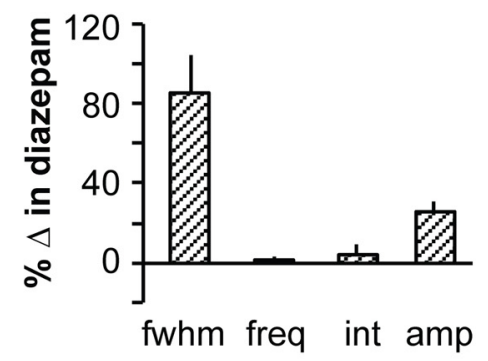

D

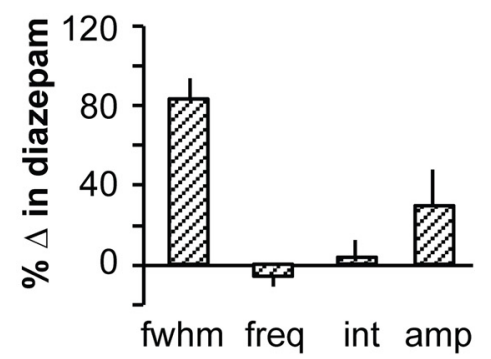

Figure 5. Postsynaptic GABA $A_{A}$ receptors on hypothalamic kisspeptin neurons are not saturated by the amount of GABA released during an mPSC. $A, C$, Representative mean $m$ PSC amplitude (left) and normalized mean amplitude (right) under control conditions (black) and in the presence of diazepam (red) in arcuate nucleus $(\boldsymbol{A})$ and AVPV (C) kisspeptin neurons. $\boldsymbol{B}, \boldsymbol{D}$, Mean \pm SEM effects of diazepam reported as \% change in arcuate nucleus $(\boldsymbol{B})$ and AVPV $(\boldsymbol{D})$ kisspeptin neurons. fwhm, Full-width at half-maximum; freq, frequency; int, interevent interval; amp, amplitude. N is reported as the number of recordings/number of animals: arcuate 6/6, AVPV $3 / 3$.

\section{Assessment of postsynaptic receptor saturation in AVPV kisspeptin neurons}

Because there was no change in mPSC amplitude, we used AVPV kisspeptin neurons as a negative control for the ability of NSFA to detect changes in the number of receptors $(\mathrm{N})$. Notably, the high frequency of mPSCs and their very long decay time in AVPV neurons in the presence of diazepam made it difficult to identify isolated events for analysis. We first tested the effect of increasing $\mathrm{GABA}_{\mathrm{A}}$ receptor affinity on amplitude in AVPV kisspeptin neurons (Fig. $5 C, D)$. In all AVPV kisspeptin cells analyzed $(n=3)$, diazepam increased full-width at half-maximum (Kolmogorov-Smirnov, $p<0.01$ ) and did not alter mPSC frequency or interval. Diazepam also increased the amplitude of mPSCs (Kolmogorov-Smirnov, $p<0.01$ ); however, only two recordings met the stringent NSFA criteria because of the high-frequency/long decay characteristics mentioned above. In these two recordings, NSFA revealed that diazepam induced a modest increase in estimates of both $\mathrm{N}$ and $\mathrm{g}$ in AVPV kisspeptin neurons. As expected from the lack of effect of estradiol on mPSC amplitude in AVPV kisspeptin neurons, we found no difference in $g$ or $\mathrm{N}$ with estradiol treatment (N: OVX $37.9 \pm$ 8.7 vs OVX +E $37.4 \pm 8.9$; g: OVX $62.6 \pm 10.0 \mathrm{pS}$ vs OVX $+\mathrm{E}$ $57.4 \pm 5.0 \mathrm{pS} ; p>0.5$; Fig. $6 F$ ).

\section{Discussion}

Changes in estradiol feedback action, often diurnal, are critical for inducing the central signal for ovulation (Döcke and Dörner, 1965). Integration of steroid and diurnal cues likely occurs upstream of GnRH neurons because these cells lack $\mathrm{ER} \alpha$ needed for feedback action. Here we demonstrate that both estradiol and time of day influence GABAergic transmission to hypothalamic kisspeptin neurons as well as their response to GABA. Estradiol feedback both at kisspeptin neurons and their afferents is thus likely to be critical for control of female fertility.

Two main elements regulate the outcome of synaptic interactions: presynaptic release of neurotransmitter and postsynaptic response. Together, these determine the subsequent output of postsynaptic neurons. Presynaptic factors include the amount and frequency of transmitter released, and the number of synapses. For ionotropic $\mathrm{GABA}_{\mathrm{A}}$ receptors, postsynaptic response depends on the reversal potential of the permeant chloride ion, the baseline membrane potential, and other postsynaptic factors, including input resistance and voltage-gated conductances.

GABAergic interactions in two hypothalamic populations expressing kisspeptin were studied. We used an OVX+E model in which there are diurnal changes between estradiol negative feedback in the AM and positive feedback in the PM measured as GnRH/LH release and GnRH neuron activity (Christian et al., 2005; Glanowska et al., 2012), and OVX mice in which no diurnal variation has been observed in those variables. We first investigated postsynaptic responsiveness, starting with chloride homeostasis. There was no effect of estradiol or time of day on reversal potential of current through the $\mathrm{GABA}_{\mathrm{A}}$ receptor within either kisspeptin population studied, despite reports in other hypothalamic systems that both factors can modulate function of the electroneutral cotransporters that determine intracellular chloride concentration and thus reversal potential (De Jeu and Pennartz, 2002; Shimura et al., 2002; Perrot-Sinal et al., 2007; Nugent et al., 2012). Reversal potential did, however, differ with region, being more depolarized in arcuate nucleus than AVPV neurons, suggesting these populations are differentially responsive to GABAergic input, an aspect that could underlie postulated different roles for arcuate nucleus and AVPV neurons in regulating GnRH output (Oakley et al., 2009). 
A

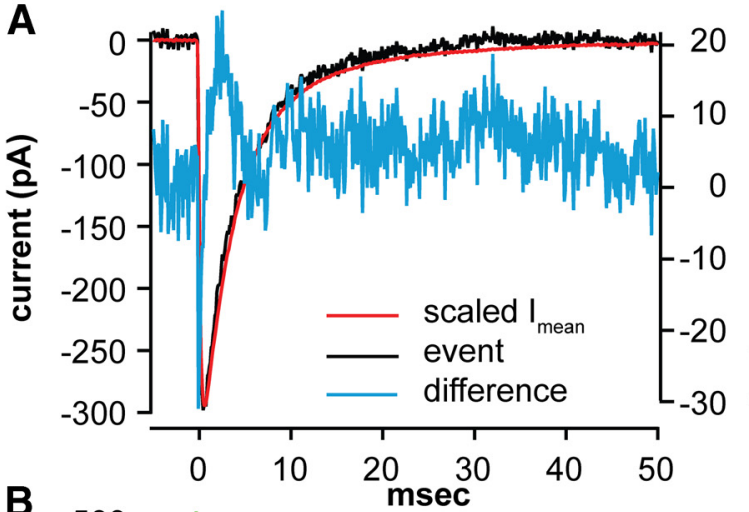

B
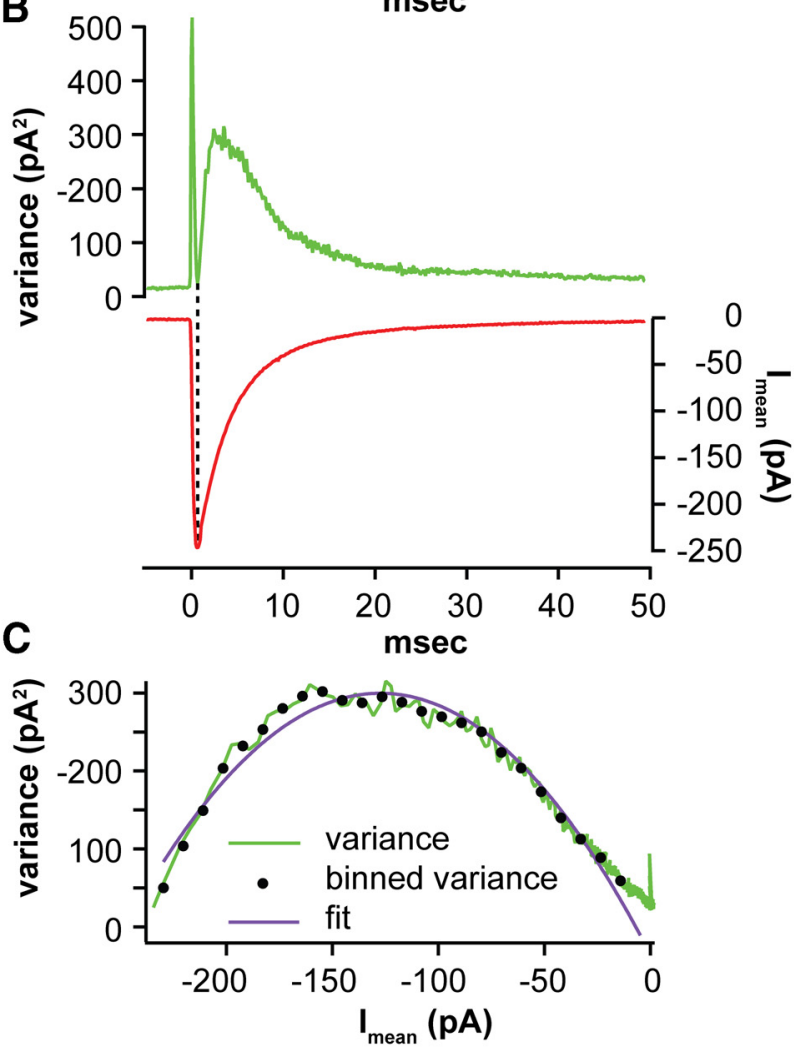

D $\square$ control

$\square$ diazepam
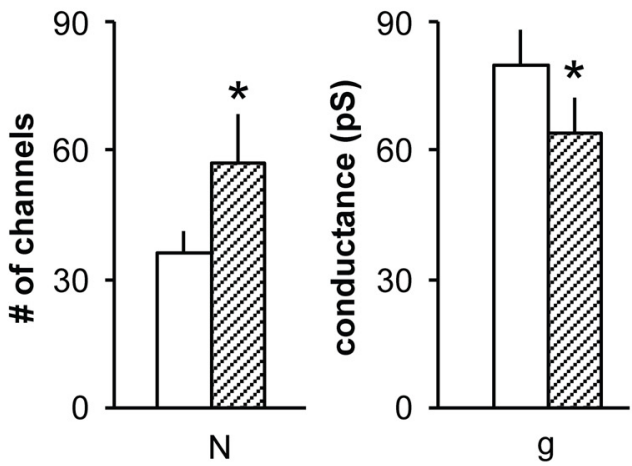

$\mathbf{E}$
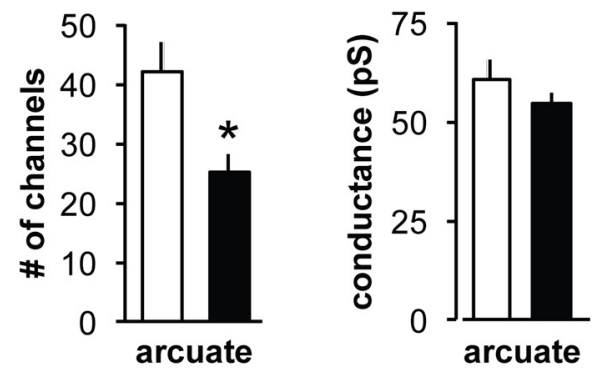

$\mathbf{F}$

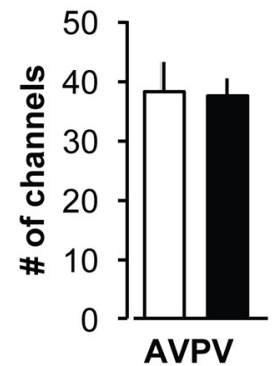

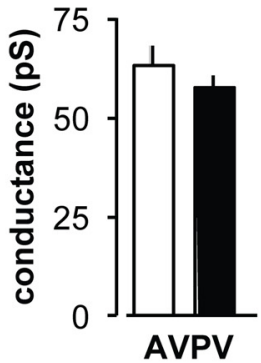

Figure 6. Peak scaled NSFA to estimate single-channel conductance $(\mathrm{g})$ and number of receptors (N). $\boldsymbol{A}$, Variance (blue, right ordinate) was calculated by subtracting the scaled mean current ( $I_{\text {mean }}$, red) from the current during an individual event (black). B, Top, Mean variance (difference squared, green). Bottom, Mean current (red). $\boldsymbol{C}$, Estimation of $\mathrm{N}$ and $\mathrm{g}$ using a parabolic fit (purple) to the binned variance (black dots) plotted as a function of $\mathrm{I}_{\text {mean }}$. Variance $=\mathrm{i} \mathrm{I}_{\text {mean }}-\mathrm{I}_{\text {mean }}{ }^{2} / \mathrm{N}$. Single-channel conductance, $g$, is calculated from the single-channel current (i) and the driving force. D, NSFA of arcuate nucleus kisspeptin mPSCs that responded with a change in amplitude in the presence of diazepam ( $n=5$ of 6 ). Data are mean \pm SEM (N and g). ${ }^{*} p<0.05$. E, NSFA of arcuate nucleus kisspeptin mPSCs reveals that estradiol dampens mPSC amplitude by decreasing the number of receptors bound by GABA. Data are mean \pm SEM (N and g). ${ }^{*} p<0.05 . n=8$ OVX PM, 6 OVX $+E$ PM (one animal per recording). $F$, Data are mean \pm SEM (N and g) in AVPV kisspeptin neurons. $n=5$ OVX $\mathrm{PM}, 4 \mathrm{OVX}+\mathrm{E} \mathrm{PM}$ (one animal per recording).

To study the membrane response to GABA, we used a technique that maintains native intracellular chloride and minimally disturbs membrane potential (Fricker et al., 1999; Verheugen et al., 1999). Arcuate nucleus neurons were indeed depolarized by GABA, whereas AVPV neurons were hyperpolarized, supporting and extending the measurements of reversal potential. Interestingly, unlike reversal potential, membrane response to GABA in arcuate nucleus kisspeptin neurons was estradiol-sensitive, with only neurons from estradiol-treated mice responding with the strong depolarization predicted by the measured baseline membrane potential and GABA reversal potential. Despite a similar strong depolarizing driving force in cells from OVX mice, GABA failed to alter membrane potential. This suggests that in the absence of estradiol, some postsynaptic feature(s) (e.g., potassium channels) blunts the depolarizing response to GABA, and estradiol maintains the response to GABA by relieving this blunting mechanism. Initial support for this postulate comes from the observed estradiol-induced increase in input resistance of arcuate nucleus kisspeptin neurons, indicating fewer channels open at baseline. This estradiol-induced increase in input resistance could contribute to the greater depolarization in OVX $+\mathrm{E}$ arcuate nucleus neurons. Of note, even the greater GABA-induced depolarization in arcuate nucleus neurons from estradiol-treated mice is likely to be subthreshold; thus, GABA is not likely to be directly excitatory. The depolarizing response could, however, sum with subthreshold glutamatergic postsynaptic potentials, or sufficiently activate voltage-gated conductances to induce indirectly action potential firing. Alternatively, the conductance increase 
attributable to opening $\mathrm{GABA}_{\mathrm{A}}$ receptors could diminish the response to other changes in current ("shunting inhibition"). Additionally, the depolarization could be sufficient to inactivate voltage-gated sodium channels and result in an increased threshold for action potential firing ("depolarizing inhibition"). The latter of these would be enhanced in cells from estradiol-treated mice, consistent with the current view that steroid negative feedback is conveyed to GnRH neurons at least in part by inhibition of arcuate nucleus kisspeptin neurons (Oakley et al., 2009; Mayer et al., 2010).

In AVPV neurons, the hyperpolarized GABA reversal potential corresponded with GABA-induced hyperpolarization in all groups except cells from OVX mice studied in the evening. In contrast to the arcuate nucleus where removal of estradiol altered the response to GABA by changing the membrane potential achieved during GABA application, in OVX PM AVPV neurons, the loss of hyperpolarizing response to GABA was attributable to hyperpolarization of the baseline membrane potential to near the reversal potential. This neutralizes the electrochemical gradient for chloride flux, resulting in a shunting response to GABA in this group. Of note, this group had the highest frequency of GABAergic input; it is possible this barrage contributes to driving baseline membrane potential toward the reversal potential. In all groups studied, GABA is likely to inhibit AVPV kisspeptin neurons, although it is important to bear in mind that these neurons exhibit rebound excitation following strong hyperpolarization (Piet et al., 2013). This effect would likely be stronger in cells from OVX $+\mathrm{E}$ than OVX mice during the PM and could result in increased output contributing to estradiol positive feedback at this time.

The intrinsic characteristics of kisspeptin neurons considered above help determine response when these cells receive GABAergic transmission. Estradiol and time of day also altered GABAergic synaptic transmission. Both arcuate nucleus and AVPV kisspeptin neurons from OVX mice displayed increased sPSC frequency in the PM versus the AM. In GnRH neurons from mice prepared in these same animal models, no diurnal change in any synaptic or intrinsic variable studied has yet been observed unless estradiol was present (Christian and Moenter, 2007, 2010; Christian et al., 2008). A previous study did not detect an effect of estradiol on PSC frequency in kisspeptin neurons; however, time of day was not considered (Frazão et al., 2013). The present observations are thus the first indication of a possible estradiolindependent time of day signal to a component of the reproductive neuroendocrine circuitry. In both arcuate nucleus and AVPV kisspeptin populations, the PM elevation in PSC frequency persisted when presynaptic activity was blocked, suggesting time of day-dependent remodeling of the GABAergic inputs to kisspeptin neurons. That is, the number of release sites, as well as presynaptic activity, is increased in the PM. Given the requirement of estradiol treatment to observe a diurnal change in the properties of $\mathrm{GnRH}$ neurons, it is interesting that estradiol treatment blunted the PM increase in sPSC and mPSC frequency in both kisspeptin populations. This indicates that as yet unidentified neurons presynaptic to kisspeptin neurons are also targets of estradiol feedback.

In the arcuate nucleus, sPSC amplitude was decreased both by estradiol (OVX AM vs OVX +E AM) and in the PM relative to the AM (OVX AM > OVX PM). Almost the opposite was observed in the AVPV in which amplitude was enhanced by estradiol in the $\mathrm{PM}(\mathrm{OVX}+\mathrm{E} \mathrm{PM}<\mathrm{OVX} \mathrm{PM}$ or OVX+E AM), as previously observed (Frazão et al., 2013). When action potentials are blocked, no group differences were observed in the AVPV, whereas the estradiol-dependent decrease in amplitude persisted in arcuate nucleus neurons. Further, the amplitude of sPSCs and mPSCs was not different in arcuate nucleus kisspeptin neurons within a treatment. Assuming the same postsynaptic receptors are activated during sPSCs and mPSCs, action potential-driven and single-vesicle releases likely activate a similar number of postsynaptic receptors. Configurations that could result in this observation include the following: (1) saturation of postsynaptic $\mathrm{GABA}_{\mathrm{A}} \mathrm{Rs}$ by contents of a single vesicle; or (2) both action potential-driven and single-vesicle release liberate the same amount of GABA. We tested the first option by increasing $\mathrm{GABA}_{\mathrm{A}}$ receptor affinity using the benzodiazepine agonist diazepam. Diazepam increased mPSC amplitude in the majority of recordings in both kisspeptin populations, providing strong evidence that postsynaptic receptors are not saturated by the amount of GABA released during an MPSC.

Because postsynaptic receptors are not saturated by synaptic release of $\mathrm{GABA}$, regulation of $\mathrm{GABA}_{\mathrm{A}}$ receptor number and/or activation could account for the estradiol-induced suppression of mPSC amplitude in arcuate nucleus kisspeptin neurons. Using peak-scaled NSFA of the decay phase of $\mathrm{mP}$ SCs to indirectly estimate the properties of synaptic $\mathrm{GABA}_{\mathrm{A}} \mathrm{Rs}$ (De Koninck and Mody, 1994; Hartveit and Veruki, 2007), we found that the number of receptors activated by GABA was decreased, although no change in conductance was detected. A parallel analysis of AVPV mPSCs revealed no change in estimates of receptor number or conductance, consistent with the lack of effect of estradiol on mPSC amplitude in these cells.

Both chloride homoeostatic mechanisms and synaptic transmission are developmentally regulated in many brain regions (Farrant and Kaila, 2007; Ben-Ari et al., 2012). Possible changes in GABAergic signaling to kisspeptin neurons and their response will be important to consider with regard to the role of kisspeptin neurons in puberty. The present studies in adults reveal that time of day and estradiol alter GABA regulation of kisspeptin neurons in female mice. Together with previous work on GnRH neurons, these findings detail an important role for GABA in a complex reproductive neuroendocrine network that ultimately drives GnRH release. The present data also indicate that targets for estradiol feedback extend upstream of kisspeptin neurons, broadening the network for future studies.

\section{References}

Barberis A, Petrini EM, Mozrzymas JW (2011) Impact of synaptic neurotransmitter concentration time course on the kinetics and pharmacological modulation of inhibitory synaptic currents. Front Cell Neurosci 5:6. CrossRef Medline

Barry PH (1994) JPCalc, a software package for calculating liquid junction potential corrections in patch-clamp, intracellular, epithelial and bilayer measurements and for correcting junction potential measurements. J Neurosci Methods 51:107-116. CrossRef Medline

Ben-Ari Y, Woodin MA, Sernagor E, Cancedda L, Vinay L, Rivera C, Legendre P, Luhmann HJ, Bordey A, Wenner P, Fukuda A, van den Pol AN, Gaiarsa JL, Cherubini E (2012) Refuting the challenges of the developmental shift of polarity of GABA actions: GABA more exciting than ever! Front Cell Neurosci 6:35. CrossRef Medline

Christian CA, Moenter SM (2007) Estradiol induces diurnal shifts in GABA transmission to gonadotropin-releasing hormone neurons to provide a neural signal for ovulation. J Neurosci 27:1913-1921. CrossRef Medline

Christian CA, Moenter SM (2010) The neurobiology of preovulatory and estradiol-induced gonadotropin-releasing hormone surges. Endocr Rev 31:544-577. CrossRef Medline

Christian CA, Mobley JL, Moenter SM (2005) Diurnal and estradiol- 
dependent changes in gonadotropin-releasing hormone neuron firing activity. Proc Natl Acad Sci U S A 102:15682-15687. CrossRef Medline

Christian CA, Glidewell-Kenney C, Jameson JL, Moenter SM (2008) Classical estrogen receptor alpha signaling mediates negative and positive feedback on gonadotropin-releasing hormone neuron firing. Endocrinology 149:5328-5334. CrossRef Medline

Colquhoun D (1998) Binding, gating, affinity and efficacy: the interpretation of structure-activity relationships for agonists and of the effects of mutating receptors. Br J Pharmacol 125:924-947. CrossRef Medline

Colquhoun D (2006) Agonist-activated ion channels. Br J Pharmacol 147 [Suppl 1]:S17-S26.

Colquhoun D, Sakmann B (1998) From muscle endplate to brain synapses: a short history of synapses and agonist-activated ion channels. Neuron 20:381-387. CrossRef Medline

Cravo RM, Frazão R, Perello M, Osborne-Lawrence S, Williams KW, Zigman JM, Vianna C, Elias CF (2013) Leptin signaling in Kiss1 neurons arises after pubertal development. PLoS One 8:e58698. CrossRef Medline

DeFazio RA, Hablitz JJ (2001) Chloride accumulation and depletion during GABA(A) receptor activation in neocortex. Neuroreport 12:2537-2541. CrossRef Medline

DeFazio RA, Heger S, Ojeda SR, Moenter SM (2002) Activation of A-type gamma-aminobutyric acid receptors excites gonadotropin-releasing hormone neurons. Mol Endocrinol 16:2872-2891. CrossRef Medline

Defazio T, Hablitz JJ (1998) Zinc and zolpidem modulate mIPSCs in rat neocortical pyramidal neurons. J Neurophysiol 80:1670-1677. Medline

De Jeu M, Pennartz C (2002) Circadian modulation of GABA function in the rat suprachiasmatic nucleus: excitatory effects during the night phase. J Neurophysiol 87:834-844. Medline

De Koninck Y, Mody I (1994) Noise analysis of miniature IPSCs in adult rat brain slices: properties and modulation of synaptic GABAA receptor channels. J Neurophysiol 71:1318-1335. Medline

Döcke F, Dörner G (1965) The mechanism of the induction of ovulation by oestrogens. J Endocrinol 33:491-499. CrossRef Medline

Dumalska I, Wu M, Morozova E, Liu R, van den Pol A, Alreja M (2008) Excitatory effects of the puberty-initiating peptide kisspeptin and group I metabotropic glutamate receptor agonists differentiate two distinct subpopulations of gonadotropin-releasing hormone neurons. J Neurosci 28: 8003-8013. CrossRef Medline

Farrant M, Kaila K (2007) The cellular, molecular and ionic basis of GABA(A) receptor signalling. Prog Brain Res 160:59-87. CrossRef Medline

Frazão R, Cravo RM, Donato J Jr, Ratra DV, Clegg DJ, Elmquist JK, Zigman JM, Williams KW, Elias CF (2013) Shift in Kiss1 cell activity requires estrogen receptor alpha. J Neurosci 33:2807-2820. CrossRef Medline

Fricker D, Verheugen JA, Miles R (1999) Cell-attached measurements of the firing threshold of rat hippocampal neurones. J Physiol 517:791-804. CrossRef Medline

Gielen MC, Lumb MJ, Smart TG (2012) Benzodiazepines modulate GABAA receptors by regulating the preactivation step after GABA binding. J Neurosci 32:5707-5715. CrossRef Medline

Glanowska KM, Venton BJ, Moenter SM (2012) Fast scan cyclic voltammetry as a novel method for detection of real-time gonadotropin-releasing hormone release in mouse brain slices. J Neurosci 32:14664-14669. CrossRef Medline

Han SK, Gottsch ML, Lee KJ, Popa SM, Smith JT, Jakawich SK, Clifton DK, Steiner RA, Herbison AE (2005) Activation of gonadotropin-releasing hormone neurons by kisspeptin as a neuroendocrine switch for the onset of puberty. J Neurosci 25:11349-11356. CrossRef Medline

Hartveit E, Veruki ML (2007) Studying properties of neurotransmitter receptors by non-stationary noise analysis of spontaneous postsynaptic currents and agonist-evoked responses in outside-out patches. Nat Protoc 2:434-448. CrossRef Medline

Herbison AE, Theodosis DT (1992) Localization of oestrogen receptors in preoptic neurons containing neurotensin but not tyrosine hydroxylase, cholecystokinin or luteinizing hormone-releasing hormone in the male and female rat. Neuroscience 50:283-298. CrossRef Medline

Herbison AE, Robinson JE, Skinner DC (1993) Distribution of estrogen receptor-immunoreactive cells in the preoptic area of the ewe: co-localization with glutamic acid decarboxylase but not luteinizing hormone-releasing hormone. Neuroendocrinology 57:751-759. CrossRef Medline

Hrabovszky E, Shughrue PJ, Merchenthaler I, Hajszán T, Carpenter CD, Liposits Z, Petersen SL (2000) Detection of estrogen receptor-beta mes- senger ribonucleic acid and 125I-estrogen binding sites in luteinizing hormone-releasing hormone neurons of the rat brain. Endocrinology 141:3506-3509. CrossRef Medline

Hrabovszky E, Ciofi P, Vida B, Horvath MC, Keller E, Caraty A, Bloom SR, Ghatei MA, Dhillo WS, Liposits Z, Kallo I (2010) The kisspeptin system of the human hypothalamus: sexual dimorphism and relationship with gonadotropin-releasing hormone and neurokinin B neurons. Eur J Neurosci 31:1984-1998. CrossRef Medline

Kalsbeek A, Palm IF, La Fleur SE, Scheer FA, Perreau-Lenz S, Ruiter M, Kreier F, Cailotto C, Buijs RM (2006) SCN outputs and the hypothalamic balance of life. J Biol Rhythms 21:458-469. CrossRef Medline

Karsch FJ, Cummins JT, Thomas GB, Clarke IJ (1987) Steroid feedback inhibition of pulsatile secretion of gonadotropin-releasing hormone in the ewe. Biol Reprod 36:1207-1218. CrossRef Medline

Legan SJ, Karsch FJ (1975) A daily signal for the LH surge in the rat. Endocrinology 96:57-62. CrossRef Medline

Lehman MN, Ebling FJ, Moenter SM, Karsch FJ (1993) Distribution of estrogen receptor-immunoreactive cells in the sheep brain. Endocrinology 133:876-886. CrossRef Medline

Lehman MN, Merkley CM, Coolen LM, Goodman RL (2010) Anatomy of the kisspeptin neural network in mammals. Brain Res 1364:90-102. CrossRef Medline

Mayer C, Acosta-Martinez M, Dubois SL, Wolfe A, Radovick S, Boehm U, Levine JE (2010) Timing and completion of puberty in female mice depend on estrogen receptor alpha-signaling in kisspeptin neurons. Proc Natl Acad Sci U S A 107:22693-22698. CrossRef Medline

Miller BH, Takahashi JS (2013) Central circadian control of female reproductive function. Front Endocrinol (Lausanne) 4:195. CrossRef Medline

Moenter SM, Caraty A, Karsch FJ (1990) The estradiol-induced surge of gonadotropin-releasing hormone in the ewe. Endocrinology 127:13751384. CrossRef Medline

Moenter SM, Caraty A, Locatelli A, Karsch FJ (1991) Pattern of gonadotropin-releasing hormone $(\mathrm{GnRH})$ secretion leading up to ovulation in the ewe: existence of a preovulatory GnRH surge. Endocrinology 129:1175-1182. CrossRef Medline

Norman RL, Blake CA, Sawyer CH (1973) Estrogen-dependent 24-hour periodicity in pituitary $\mathrm{LH}$ release in the female hamster. Endocrinology 93:965-970. CrossRef Medline

Nugent BM, Valenzuela CV, Simons TJ, McCarthy MM (2012) Kinases SPAK and OSR1 are upregulated by estradiol and activate NKCC1 in the developing hypothalamus. J Neurosci 32:593-598. CrossRef Medline

Oakley AE, Clifton DK, Steiner RA (2009) Kisspeptin signaling in the brain. Endocr Rev 30:713-743. CrossRef Medline

Perrais D, Ropert N (1999) Effect of zolpidem on miniature IPSCs and occupancy of postsynaptic GABAA receptors in central synapses. J Neurosci 19:578-588. Medline

Perrot-Sinal TS, Sinal CJ, Reader JC, Speert DB, McCarthy MM (2007) Sex differences in the chloride cotransporters, NKCC1 and KCC2, in the developing hypothalamus. J Neuroendocrinol 19:302-308. CrossRef Medline

Pielecka-Fortuna J, Chu Z, Moenter SM (2008) Kisspeptin acts directly and indirectly to increase gonadotropin-releasing hormone neuron activity and its effects are modulated by estradiol. Endocrinology 149:1979-1986. CrossRef Medline

Piet R, Boehm U, Herbison AE (2013) Estrous cycle plasticity in the hyperpolarization-activated current ih is mediated by circulating 17betaestradiol in preoptic area kisspeptin neurons. J Neurosci 33:1082810839. CrossRef Medline

Robertson JL, Clifton DK, de la Iglesia HO, Steiner RA, Kauffman AS (2009) Circadian regulation of Kiss1 neurons: implications for timing the preovulatory gonadotropin-releasing hormone/luteinizing hormone surge. Endocrinology 150:3664-3671. CrossRef Medline

Robinson RA, Stokes RH (1959) Electrolyte solutions. London: Butterworths.

Ruka KA, Burger LL, Moenter SM (2013) Regulation of arcuate neurons coexpressing kisspeptin, neurokinin $\mathrm{B}$, and dynorphin by modulators of neurokinin 3 and kappa-opioid receptors in adult male mice. Endocrinology 154:2761-2771. CrossRef Medline

Saeb-Parsy K, Lombardelli S, Khan FZ, McDowall K, Au-Yong IT, Dyball RE (2000) Neural connections of hypothalamic neuroendocrine nuclei in the rat. J Neuroendocrinol 12:635-648. CrossRef Medline

Sarkar DK, Fink G (1979) Effects of gonadal steroids on output of luteiniz- 
ing hormone releasing factor into pituitary stalk blood in the female rat. J Endocrinol 80:303-313. CrossRef Medline

Shimura M, Akaike N, Harata N (2002) Circadian rhythm in intracellular $\mathrm{Cl}(-)$ activity of acutely dissociated neurons of suprachiasmatic nucleus. Am J Physiol Cell Physiol 282:C366-C373. CrossRef Medline

Smith JT, Cunningham MJ, Rissman EF, Clifton DK, Steiner RA (2005) Regulation of Kiss1 gene expression in the brain of the female mouse. Endocrinology 146:3686-3692. CrossRef Medline

Sullivan SD, DeFazio RA, Moenter SM (2003) Metabolic regulation of fertility through presynaptic and postsynaptic signaling to gonadotropinreleasing hormone neurons. J Neurosci 23:8578-8585. Medline

Verheugen JA, Fricker D, Miles R (1999) Noninvasive measurements of the membrane potential and GABAergic action in hippocampal interneurons. J Neurosci 19:2546-2555. Medline

Vida B, Deli L, Hrabovszky E, Kalamatianos T, Caraty A, Coen CW, Liposits Z, Kalló
I (2010) Evidence for suprachiasmatic vasopressin neurones innervating kisspeptin neurones in the rostral periventricular area of the mouse brain: regulation by oestrogen. J Neuroendocrinol 22:1032-1039. CrossRef Medline

Watts AG, Swanson LW (1987) Efferent projections of the suprachiasmatic nucleus: II. Studies using retrograde transport of fluorescent dyes and simultaneous peptide immunohistochemistry in the rat. J Comp Neurol 258:230-252. CrossRef Medline

Watts AG, Swanson LW, Sanchez-Watts G (1987) Efferent projections of the suprachiasmatic nucleus: I. Studies using anterograde transport of Phaseolus vulgaris leucoagglutinin in the rat. J Comp Neurol 258:204229. CrossRef Medline

Williams WP 3rd, Jarjisian SG, Mikkelsen JD, Kriegsfeld LJ (2011) Circadian control of kisspeptin and a gated GnRH response mediate the preovulatory luteinizing hormone surge. Endocrinology 152:595-606. CrossRef Medline 